\title{
ONREL
}

\section{Q1/Q2 2018 Solar Industry Update}

David Feldman, NREL

Robert Margolis, NREL

August 2018 


\section{Executive Summary}

- In Q1 2018, the United States installed 2.5 GW-DC of PV, $57 \%$ from the utility-scale PV market, and approximately 44 MW-AC (126 MWh) of energy storage onto the electric grid.

- Since the announcement of the Section 201 tariff on imported PV products, several manufacturers have announced U.S. manufacturing expansion plans, which are expected to push U.S. manufacturing capacity to $3 \mathrm{GW}$-DC of cells and $7 \mathrm{GW}-\mathrm{DC}$ of module assembly.

- On May 31, 2018, China, which installed over half of global PV installations in 2017, announced it would curb 2018 domestic solar installations. Analysts predict the change in Chinese policy will reduce annual Chinese installations by as much as $20 \mathrm{GW}-\mathrm{DC}$, causing a substantial reduction in global demand.

- This change in policy has resulted in an immediate oversupply of panels and associated drop in panel pricing globally.

- Module, cell, and wafer prices have dropped since the beginning of the year, but they accelerated in June and July after China terminated subsidies on new utility-scale PV projects in 2018 and reduced its FIT. In July, global module ASP was reported to be $\$ 0.26 / \mathrm{W}$.

- Modules sold in the United States in Q1 2018 were 53\% higher than the global average.

- While solar stocks outperformed the broader market in 2017, they tumbled significantly in May through July of 2018 due to lower expectations of global demand.

- 2017 was a record-breaking year with \$1.3 billion of solar asset-backed securities (ABS); this trend continues in 2018 with over $\$ 1$ billion in the first six months. 
1 Federal and State Updates

2 Global Solar Deployment

3 U.S. PV Deployment

4 PV System Pricing

5 Global Manufacturing

6 Component Pricing

7 Market Activity 


\section{Federal and State Updates}

\section{Global Solar Deployment}

\section{U.S. PV Deployment}

PV System Pricing

5 Global Manufacturing

6 Component Pricing

7 Market Activity
- Since the announcement of the Section 201 tariff on imported PV products, several manufacturers have announced U.S. manufacturing expansion plans, which are expected to push U.S. manufacturing capacity to $3 \mathrm{GW}-\mathrm{DC}$ of cells and $7 \mathrm{GW}-\mathrm{DC}$ of module assembly.

- Since the 201 tariff announcement, U.S. project developers have also announced project cancellations totaling more than $\mathbf{\$ 2 . 5}$ billion.

- A new trade case has been announced against China due to U.S. concerns of IPR. If implemented, they could increase inverter costs by $10 \%-25 \%$. 
Federal and State Updates: Manufacturing Expansion Announcements

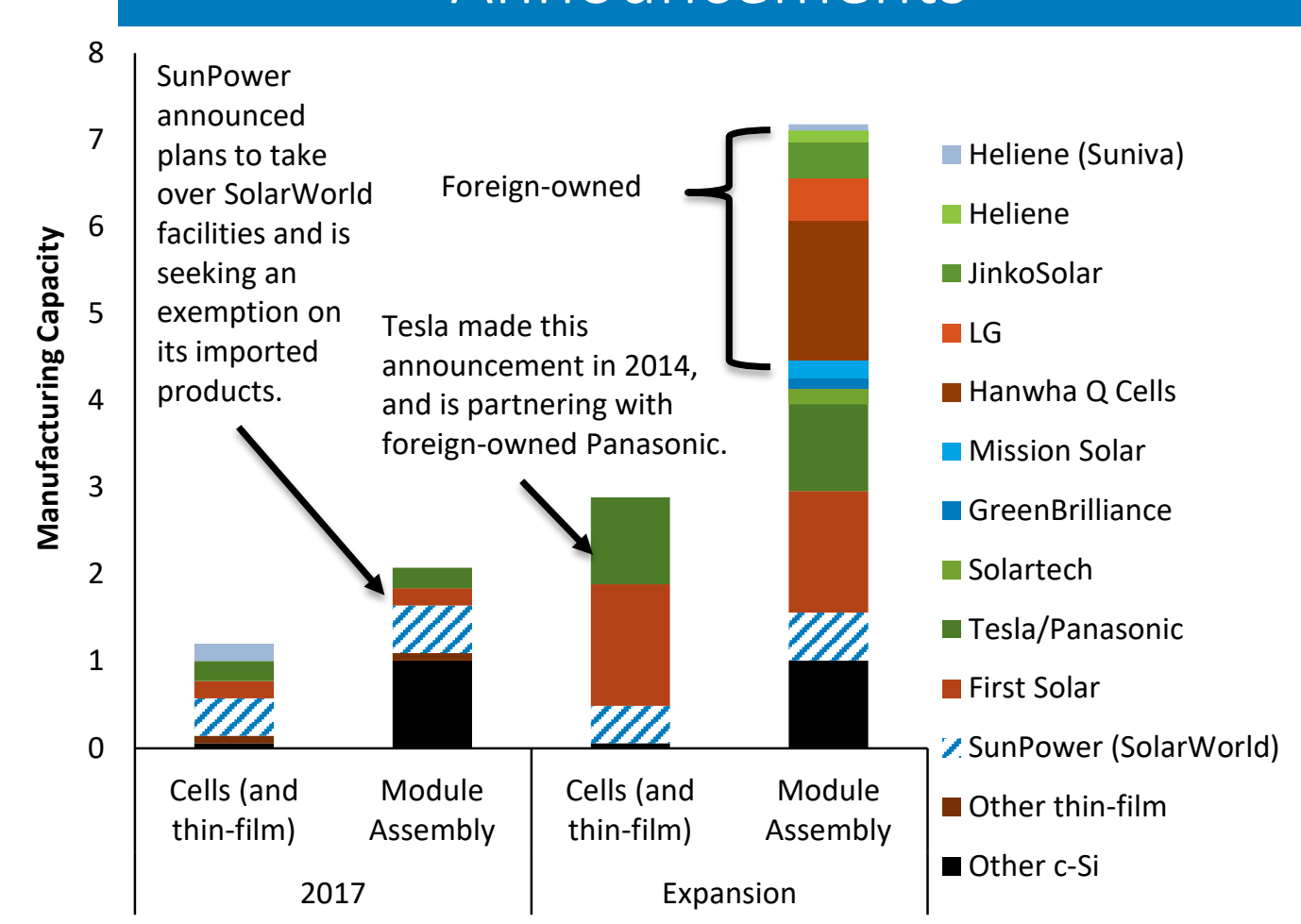

- At the end of 2017, the United States had a PV cell and module manufacturing capacities of more than $1 \mathrm{GW}$-DC and $2 \mathrm{GW}$-DC respectively.

- Since the announcement of the Section 201 tariff on imported PV products, several manufacturers have announced U.S. manufacturing expansion plans, which are expected to push U.S. manufacturing capacity to $3 \mathrm{GW}$-DC of cells and 7.2 GW-DC of module assembly.

- The companies have also announced the expansions would result in the addition of over 3,400 new or kept manufacturing jobs associated.

- If completed, the majority of new module manufacturing capacity would come from foreign-owned companies importing foreign-made cells.

- If all announced plants are built, the United States would import well in excess of the $2.5 \mathrm{GW}$-DC PV cell import exemption.

- Since the enactment of the Section 201 tariff, all manufacturing expansion announcements have been for module assembly, not c-Si cell manufacturing.

Notes: Manufacturing expansion (e.g., Itek, Solaria, and China Sunergy) and closures (e.g., SolarWorld and Suniva) also occurred in 2017 but to a much smaller degree. Additionally, the polysilicon manufacturer, REC Silicon, announced plans to layoff a significant amount of its workforce due to trade issues between the United States and China.

Sources: GTM Research and SEIA, “U.S. Solar Market Insight: 2017 Year-in-Review;” PV Magazine (02/06/18, 04/26/18, 05/21/18, 05/30/18); Reuters (01/25/18); Electrik (01/23/18); iREL I 5 Cleantechnica (04/03/18); Greentech Media (07/30/18) 


\section{Federal and State Updates: US Deployment Pipeline Contraction}

- Analysts projected a reduction in U.S. PV deployment when a tariff was put in place on imported PV modules and cells.

- GTM Research lowered its 2018 and 2019 U.S. utility-scale installation forecasts by 20\% and 17\% respectively.

- SEIA estimated a reduction of up to 23,000 jobs due to the tariff.

- Since then, several companies have announced project cancellations totaling more than $\$ 2.5$ billion and thousands of associated lost jobs.

- Solar developer Cyprus Creek announced the cancellation of 150 projects ( $20 \%$ of their pipeline) worth $\$ 1.5$ billion, which would have employed more than 3,000 workers.

- Southern Current reported canceling \$1 billion in projects.

- McCarthy Building Companies said they would employee 600 people this year instead of 1,200 because of the tariff.

- Pine Gate announced they would not construct $200 \mathrm{MW}-300 \mathrm{MW}$ or hire 30 full-time employees due to the tariff.

- Two factors could moderate this expected contraction:

- The impact on installations may be less than originally expected due to the reduction in global module prices caused by China's solar incentive changes.

- Many developers stockpiled panels before the tariffs were put into effect. 


\section{Federal and State Updates:}

History of Section 301

- Section 301 (of the Trade Act of 1974) applies to foreign acts, policies, and practices that the U.S. Trade Representative (USTR) determines either:

- Violate or are inconsistent with a trade agreement

- Are unjustifiable and burdens or restricts U.S. commerce.

- Section 301 investigations can be initiated as a result of a petition filed by an interested party or can be self-initiated by the USTR.

- Once initiated, the USTR has 12-18 months to seek a negotiated resolution.

- If a resolution is not reached, the USTR must decide whether to retaliate, typically in the form of increased tariffs on selected imports, with a value equal to the losses incurred by U.S. firms.

- Since 1974, the USTR has initiated 124 Section 301 cases, retaliating in 16 instances; however, these cases mostly occurred before the U.S. joined the WTO in 1995. Since then, most 301 investigations were brought to the WTO for resolution.

- Many of the previous Section 301 actions were against China. In 1991, and again in 1994, the USTR alleged China inadequately protects IPR. 
- In March, 2018, the USTR released the findings of its investigation finding four broad IPR-related Chinese policies that justified U.S. action under Section 301:

- China uses joint venture requirements, foreign investment restrictions, and administrative review and licensing processes to require or pressure technology transfer from U.S. companies.

- China deprives U.S. companies of the ability to set market-based terms in licensing and other technologyrelated negotiations.

- China directs and unfairly facilitates the systematic investment in, and acquisition of, U.S. companies and assets to generate large-scale technology transfer.

- China conducts and supports cyber intrusions into U.S. commercial computer networks to gain unauthorized access to commercially valuable business information. 


\section{Federal and State Updates: Actions Taken for Current Section 301 Case}

Currently, there are three sets of Section 301 measures undertaken by the U.S., two of them directly affecting the solar industry.

1. In April, the U.S. proposed implementing a $25 \%$ ad valorem tariff on an initial list of $\$ 50$ billion in Chinese goods. After public comment and multiday hearings, the list was finalized in June to \$34 billion in goods and was implemented on July 6 .

- None of these substantially impacts the solar industry.

- Companies can file for an exclusion request, but the timing and the procedures of the process have not been set.

2. In August, an additional list of products was finalized, which is also set to receive a $25 \%$ tariff.

- Solar panels were on this second list, as were iron, steel, and aluminum, which are used in wiring and racking PV systems.

China has responded to each list, implementation, or restriction of investment with its own retaliatory tariffs or restrictions, including a $25 \%$ tariff on U.S. made solar cells. Not included on China's new tariffs is U.S. made polysilicon, although existing Chinese tariffs have already impacted the U.S. polysilicon industry. Most recently, REC announced layoffs of 100 people in their Washington plant.

3. In response to China's plans to retaliate, the President directed the USTR to identify $\$ 200$ billion worth of Chinese goods for an additional $10 \%$ tariff. It was reported that the government may raise this rate to $25 \%$.

- Solar inverters are on this list.

China and the United States have held high-level talks to resolve the dispute, but both sides have also increased the number of products subject to tariffs and the level of those tariffs. 


\section{Federal and State Updates:}

Impact on the Solar industry

- Chinese solar panels are under consideration for an additional 25\% tariff, on top of the Section 201 tariff of $30 \%$, and previous AD+CVD tariffs.

- Because of existing duties on Chinese panels, only a small percentage of total module imports now come from China.

- Solar inverters and AC modules are also under consideration for a $10 \%$ tariff, which would increase U.S. inverter costs by $\$ 0.01 / \mathrm{W}-\$ 0.02 / \mathrm{W}$.

- GTM Research estimates that more than $80 \%$ of residential inverters and $50 \%$ of commercial inverters come from China.

- Some vendors will be more affected than others. For example, Enphase manufactures its products in China while SolarEdge has manufacturing facilities in North America.

- For utility-scale projects, the two largest vendors of central inverters, SMA and Power Electronics, manufacture in Europe. 


\section{Federal and State Updates: Module and Cell Import Data}

- Since the spike in demand in 2017 to avoid the Section 201 tariffs, PV module imports are at a record low level, while imported PV cells are at a relatively high level.

- Parts of these trends are due to the record low pricing occurring in the industry.

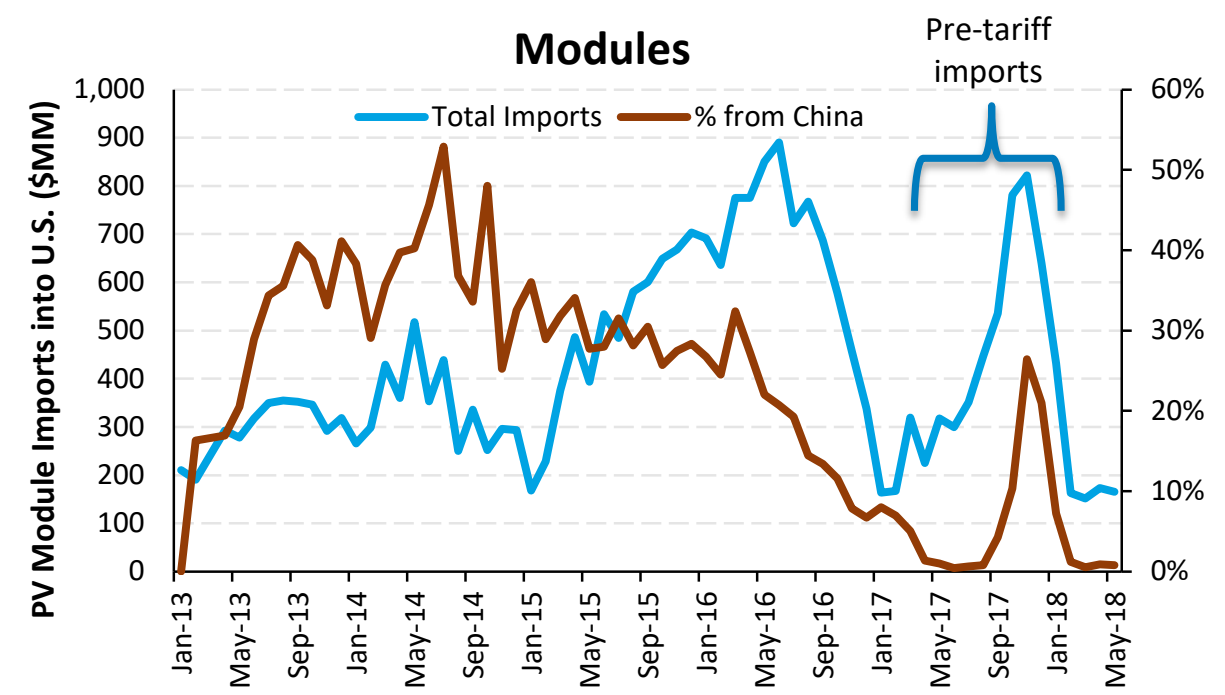

Sources: Imports, by value: U.S. International Trade Commission, 2018.
- Assuming a cell cost of $\$ 0.22 / \mathrm{W}$, the U.S. imported approximately $480 \mathrm{MW}$-DC of PV cells in the first months of 2018-significantly below the $2.5 \mathrm{GW}$-DC exempted allocation.

- Due in large part to previous tariffs levied against Chinese products, Chinese modules and cells make up a small fraction of total imports $-1 \%$ for the first 5 months of 2018 .

- New tariffs from Section 301 on Chinese goods would likely have a negligible effect on the U.S. market, because imports have already shifted from China to elsewhere.

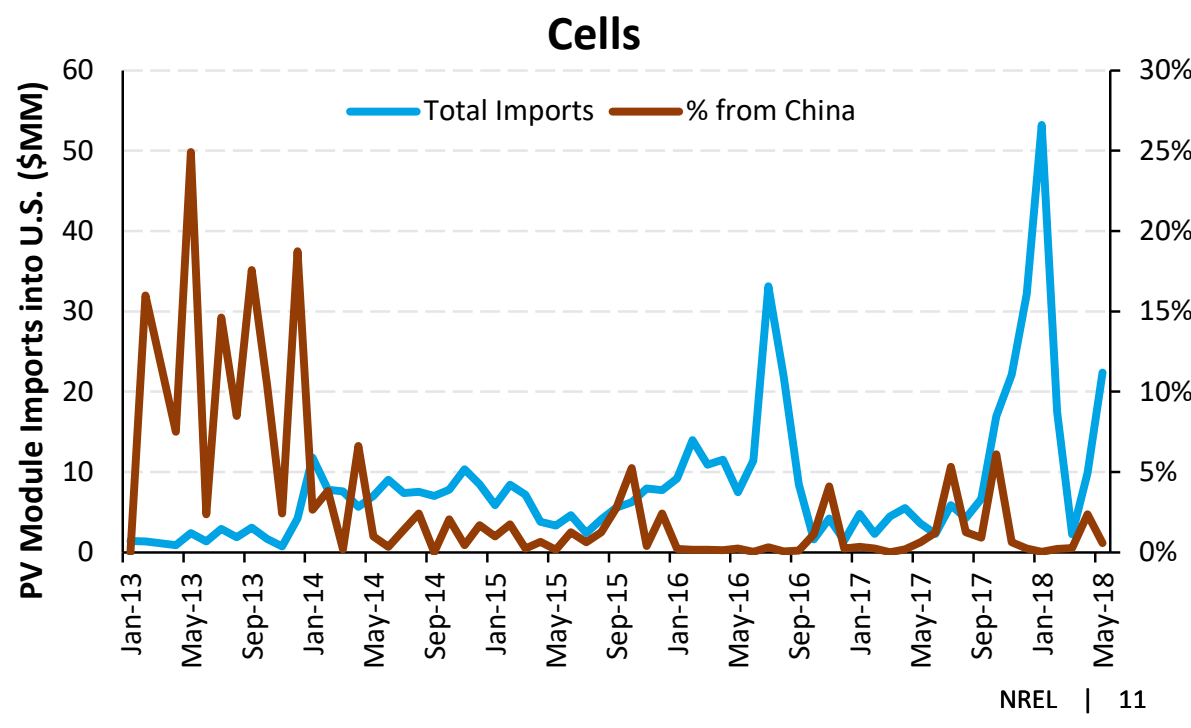


Federal and State Updates: Qualifying for the ITC through "Commence Construction"

- At the end of 2015, the ITC for PV projects was renewed for five years, and for projects owned by companies (Section 48), the law was changed so they can qualify for the tax credit if they "commence construction" in the qualifying year (as opposed to placing the project in service).

- Residential owners (Section 25D) who take the tax credit must still place the project in service in the qualifying year.

Section 25D Tax Credit (Residential) $30 \%$

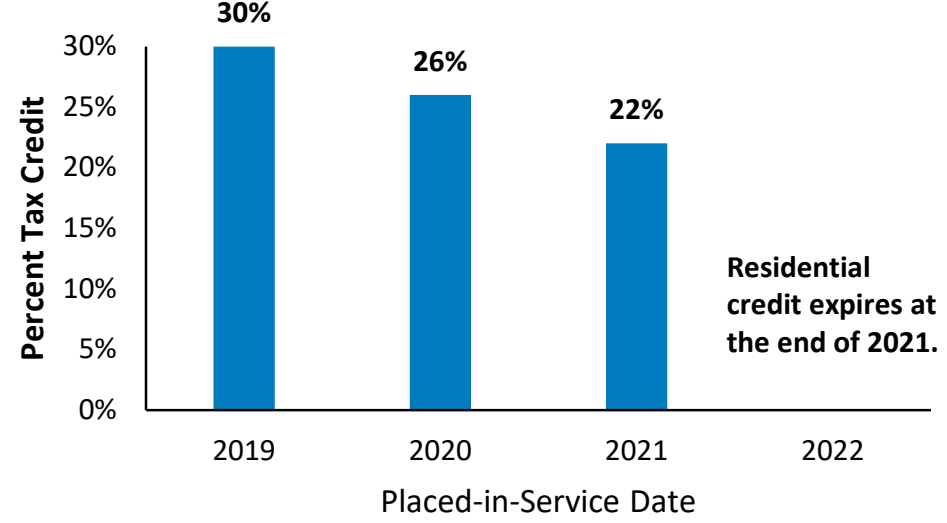

Section 48 Tax Credit (Commercial)

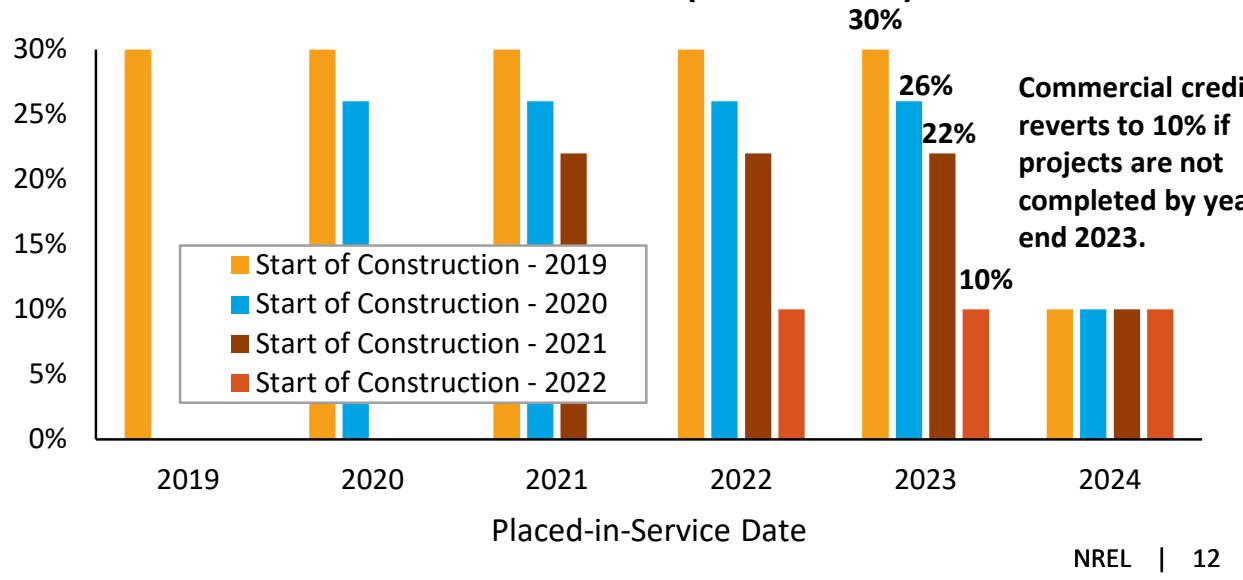

- However, without clear guidance from the IRS on how to establish when a project commences construction, investors were uncertain if they would get the full credit.
- The IRS had issued guidance on the definition of "commence construction" for wind projects to qualify for the PTC and for solar projects to qualify for the 1603 Grant in Lieu of ITC. 
Federal and State Updates: IRS Announces Guidance on "Commence

\section{Construction"}

- In June 2018, the IRS released guidance for PV system owners on establishing when a project commences construction. The guidance is similar to the guidance for wind and the 1603 program.

- The solar project is considered commenced if:

- At least $5 \%$ of final qualifying project costs are incurred.

- Expenses have to be "integral" to generating electricity, and equipment and services have to be delivered (or delivered within 3.5 months after payment).

- Or, "physical work of significant nature" is commenced on the project site or on project equipment at the factory.

- Physical work has to be "integral" to the project. Preliminary activities on site (e.g., clearing the site or building a fence or an access road) do not count as "integral."

- The project does not require proof of continuous work if it is placed in service within four years.

\section{Practical Implications}

- Developers with large balance sheets may purchase a lot of equipment in 2019 to qualify for the full $30 \%$ tax credit; however, they have until the end of 2023 to place the project in service.

- Because of the tariff on modules, developers may purchase other equipment, such as inverters, and wait to buy panels until the tariff steps down.

- Guidance puts host-owned residential PV projects at a disadvantage over leased systems, as host-owned residential systems must place the project in service in the qualifying year.

- This imbalance is exacerbated in 2022 and 2023, when TPO providers may still be able to receive a $30 \%$ ITC. 
- Section 232 of the Trade Expansion Act of 1962 is also having an impact on the solar industry beyond the effects of Section 201 and Section 301 of the Trade Act of 1974.

- Section 232 authorizes the U.S. Department of Commerce to investigate the effects of imports on national security.

- There have only been 28 Section 232 cases, and the only time tariffs were imposed in a case not involving oil was in 1986 for machine tools.

- On March 8, 2018 the president's administration concluded that imports of steel and aluminum threatened national security, and began imposing tariffs of $25 \%$ on imported steel and $10 \%$ on imported aluminum.

- On March 22, the President temporarily exempted imports of steel and aluminum from six countries and the EU.

- On May 31, it was announced that three of those countries (Brazil, Argentina, and South Korea) could negotiate exemptions with quotas, and Australia negotiated an exemption without a quota.

- On June 1, tariffs were put back on imported steel from Mexico, Canada, and the EU. 


\section{Federal and State Updates: Impact of Section 232 Tariffs on Solar}

- Steel and aluminum are critical components for ground-mounted solar and energy storage systems (and wind systems). GTM Research estimates these tariffs will increase solar LCOE by $3 \%-5 \%$, and increase energy storage prices for container-based systems by around $3 \%$.

- Steel is used for ground-mounted posts and tracker torque tubes for PV ground-mounted installations, and for housing containers for energy storage.

- The exclusion of finished goods from the tariff provides relief for certain solar products such as aluminum wiring and racking, and thus the distributed PV market should not be affected by these tariffs. 


\section{Federal and State Updates: Solar Requirements for Buildings}

- In May, the California Energy Commission voted unanimously that starting in 2020, all new residential buildings up to three stories high, including single-family homes and condos, must have solar installations.

- The panels can be either installed at individual homes or shared among several homes.

- The requirement could add $\$ 8,000-\$ 12,000$ to the cost of a home, but it could save an estimated $\$ 1,000 /$ year in utility bills. The measure is estimated to result in 65,000 additional $2.5-\mathrm{kW}$ to $4-\mathrm{kW}$ home installations per year, adding up to $260 \mathrm{MW}-\mathrm{DC}$ of new capacity annually.

- Only 3\% of total residential PV system capacity was installed on new buildings in 2017.

- In July, New York City followed suit by introducing bills requiring new office buildings, industrial facilities, and storage units to host solar PV, small wind turbines, or a green roof.

- pv magazine mentioned a permitting matter (six-foot setback) for rooftop solar in the city, which complicates installations on flat rooftops. 


\section{Federal and State Updates: Changes in Net Metering}

- Similar to actions by Michigan and Maine, Connecticut passed a law in May ending residential net metering, which will be substituted with a buy-all-sell-all incentive, allowing DG customers to use two meters (one for each direction) or a net billing option.

- In the second option, the public utility commission will set the period in which the netting of electricity occurs. Shorter periods will calculate more exported generation, resulting in more electricity receiving the lower exported rate.

- The legislation also increased the state RPS to $40 \%$ by 2030.

- In July, South Carolina reached its net metering cap of $2 \%$ total generation capacity. And, Duke Energy will now compensate residential electricity producers at reduced rates.

- A month prior, the state legislature tried and failed to raise the cap. A stakeholder group has been convened, and it hopes to have a compromise in October. 
Federal and State Updates: Overview of Net Metering and DG Compensation Policies

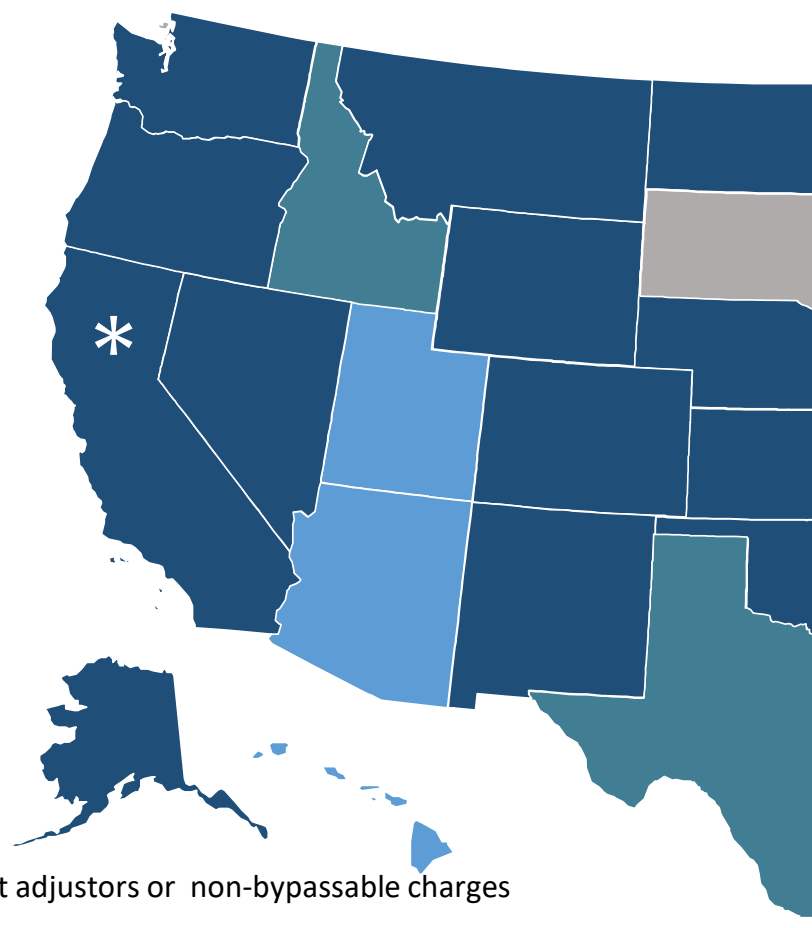

No statewide mandatory net metering rules, but some utilities offer net metering State-developed mandatory net metering rules for certain utilities
er-kWh credit adjustors or non-bypassable charges
- Arizona, Georgia, Hawaii, Maine, Mississippi, Utah: transitioned to net billing and other alternatives

- Indiana, New York: rates approved for alternative compensation mechanism

- Colorado, Michigan: transition approved, rates under development

Sources: North Carolina Clean Energy Technology Center, The 50 States of Solar: Q2 2018 Quarterly Report, July 2018. 
1 Federal and State Updates

\section{Global Solar Deployment}

\section{U.S. PV Deployment}

\section{PV System Pricing}

\section{Global Manufacturing}

6 Component Pricing
- On May 31, 2018, China, which installed over half of global PV installations in 2017, announced it would curb 2018 domestic solar installations. Analysts predict the change in Chinese policy will reduce annual Chinese installations by as much as $20 \mathrm{GW}-\mathrm{DC}$, causing a substantial reduction in global demand.

- This change in policy has resulted in an immediate oversupply of panels and associated drop in panel pricing globally. 
Global Solar Deployment: Impact of Chinese Market Changes on Global Demand

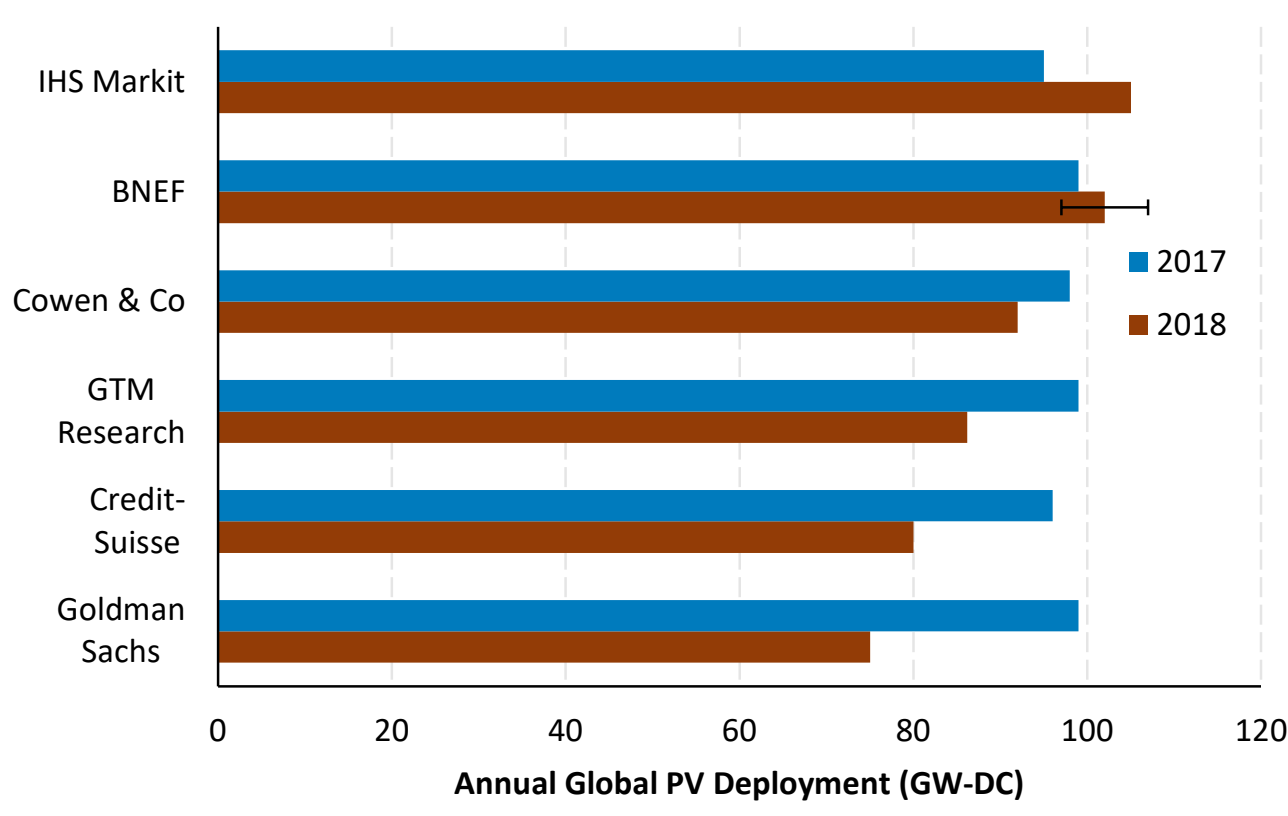

- On May 31, 2018, China, which installed over half of global PV installations in 2017, announced it would curb 2018 domestic solar installations.

- All utility-scale projects installed this year will not receive a FIT if they were not interconnected by June 1, 2018. Instead, the power price will be set by a competitive auction.

- The FIT and distributed subsidy is cut by US 0.8 cents/kWh.

- Distributed projects will be limited to $10 \mathrm{GW}$ (from $19 \mathrm{GW}$ ).

- In the first half of 2018, China had already installed 24.3 GW of PV.

- Many attribute this move by China as a response to the cost of the FIT and the large amount of PV installed away from load.

- Analysts predict the change in Chinese policy will reduce annual Chinese installations by as much as $20 \mathrm{GW}-\mathrm{DC}$, causing a substantial reduction in global demand. Most analysts think this change will cause 2018 to be the first year that the global PV market shrinks.

- This change in policy has resulted in an immediate oversupply of panels and associated drop in panel pricing globally.

Note: Error bars represent high and low projections.

Sources: Bloomberg (07/19/18); BNEF "Installed Capacity: Short-term Forecast," accessed 08/15/18; Forbes (06/18/18); PV Magazine (06/08/18) Wood Mackenzie (06/19/18). 


\section{Global Solar Deployment: Historically Low Global CSP Bids}

- In August and September of 2017, two PPAs were signed for CSP projects that broke ground in 2018:

- Aurora, which is a $150 \mathrm{MW}-\mathrm{AC}$ power tower with 8 hours of storage, signed a $\$ 0.061 / \mathrm{kWh} 20$-year PPA for $125 \mathrm{MW}$-AC of power in Southern Australia.

- DEWA IV, which is a $700 \mathrm{MW}-\mathrm{AC}$ combination of a $100 \mathrm{MW}-\mathrm{AC}$ tower with 15 hours of storage and a $600 \mathrm{MW}-\mathrm{AC}$ trough with 10 hours of storage, signed a $\$ 0.073 / \mathrm{kWh} 35$-year PPA in Dubai for power from 4 p.m. to 10 a.m.

- These PPAs were roughly half the next lowest-price CSP PPAs to date, making some think they represent a breakthrough for CSP globally. 


\section{Global Solar Deployment: How are these CSP Bids so Low?}

- Aurora has a solar resource approximately the same as other CSP projects with much higher PPAs; however, its expected installed cost is $60 \%$ lower than projects with the same configuration built five years ago.

- Current Chinese tower projects have reported similar costs.

- Troughs with storage reported similar cost reductions from 2011 to 2014.

- With the high penetration of PV, power prices are likely to continue to spike in the evening hours, and Aurora can sell its excess $25 \mathrm{MW}-\mathrm{AC}$ of capacity then.

- Southern Australian Peak pricing is typically above $\$ 75 / \mathrm{MWh}$ and occasionally reaches $10 \mathrm{x}-100 \mathrm{x}$ higher.

- DEWA IV has a relatively low solar resource; however, installation costs are projected to be low because the project is twice the size of Ivanpah (the second largest operating CSP station), which should result in economies of scale, as well as access to low-cost Chinese supply chain through partnerships.

- The project also has an extremely long PPA (35 years), which allows for a lower PPA price.

- The PPA is for the nighttime, so if sufficient heat can be collected, there could be additional daytime revenue.

- Ties to Saudi- and Chinese-state financing institutions could provide favorable financing terms and production guarantee conditions.

- Four key factors that may be replicable are (1) low installation costs, (2) the ability to sell during peaks/spikes outside the PPA, (3) a very long PPA, and (4) low financing costs.

- One might expect even lower pricing for projects with higher than average solar resources. 


\section{Federal and State Updates}

\section{Global Solar Deployment}

3 U.S. PV Deployment

4 PV System Pricing

5 Global Manufacturing

6 Component Pricing

7 Market Activity
- In Q1 2018, the United States installed 2.5 GWDC of PV, 57\% from the utility-scale PV market.

- In 2017, the U.S. community solar market doubled, growing from $347 \mathrm{MW}-\mathrm{DC}$ to 737 MW-DC.

- The United States installed approximately $44 \mathrm{MW}-\mathrm{AC}$ (126 MWh) of energy storage onto the electric grid in Q1 2018.

- From 2010 to 2017, average battery pack prices dropped $79 \%$. 


\section{U.S. PV Deployment: U.S. Installation Breakdown}

- In Q1 2018, the United States installed 2.5 GW-DC of PV.

- Utility-scale PV continues to represent the largest sector, at 57\% of quarterly installations in Q1 2018.

- Non-residential PV grew $23 \%$ y/y, driven in large part by California installations grandfathered into friendlier TOU rates and a robust Minnesota Community Solar market.

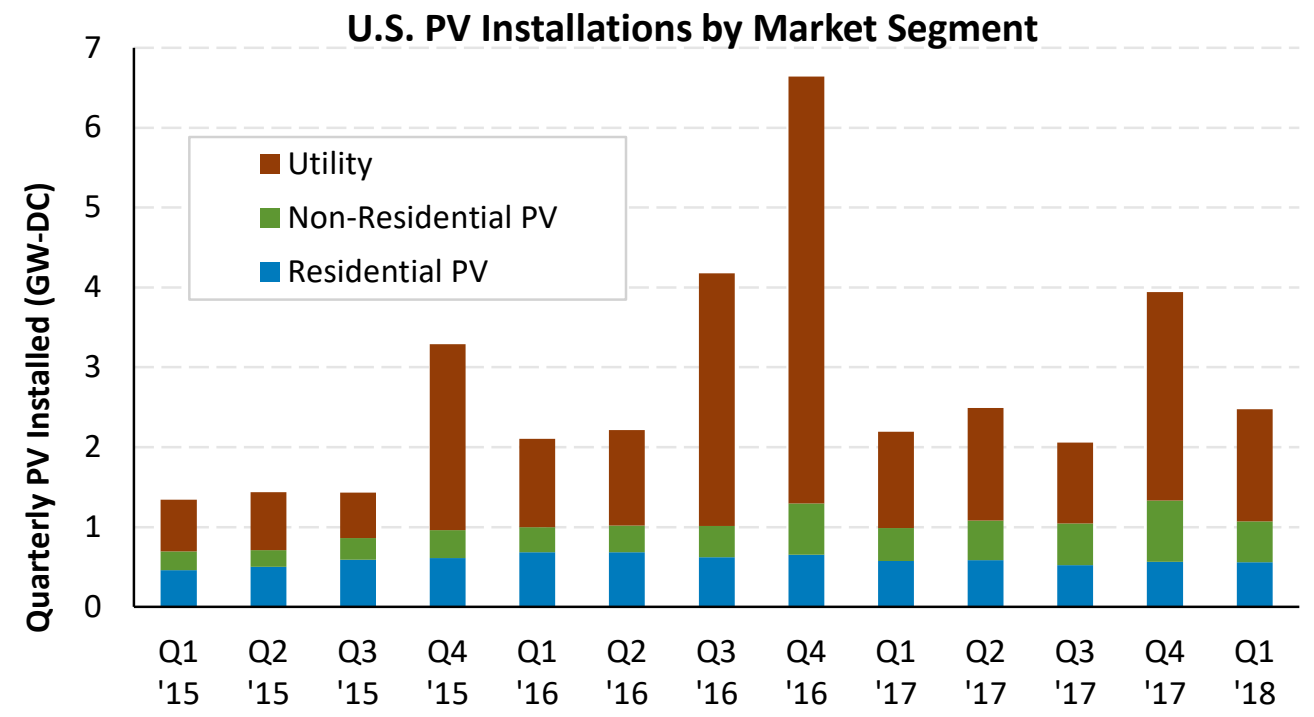

- Seven of the ten largest residential PV markets contracted in Q1 2018 due to pullback from national installers.

- That said, Florida became a top-five residential market, which should continue in the future with its PSC recently announcing that it will now permit a solar leasing product in the state.

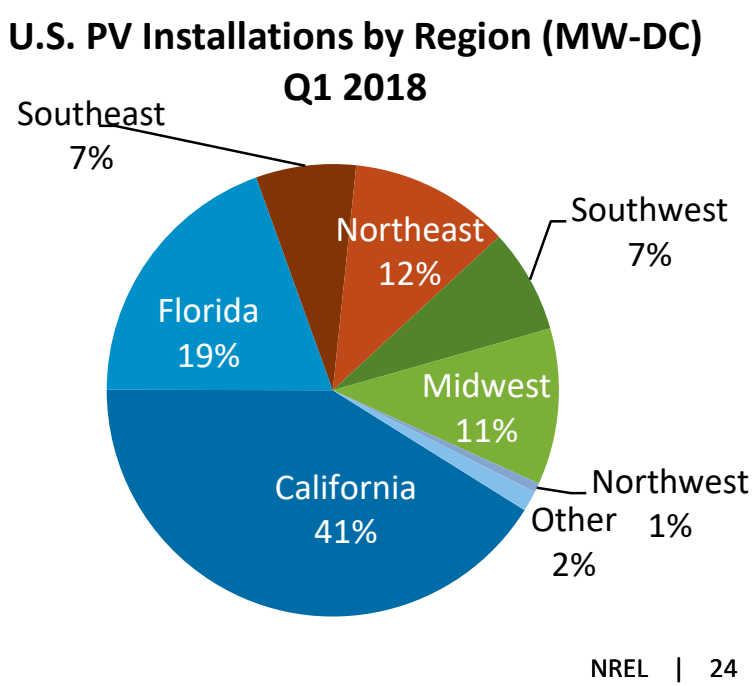


U.S. PV Deployment: Cumulative Community Solar Capacity

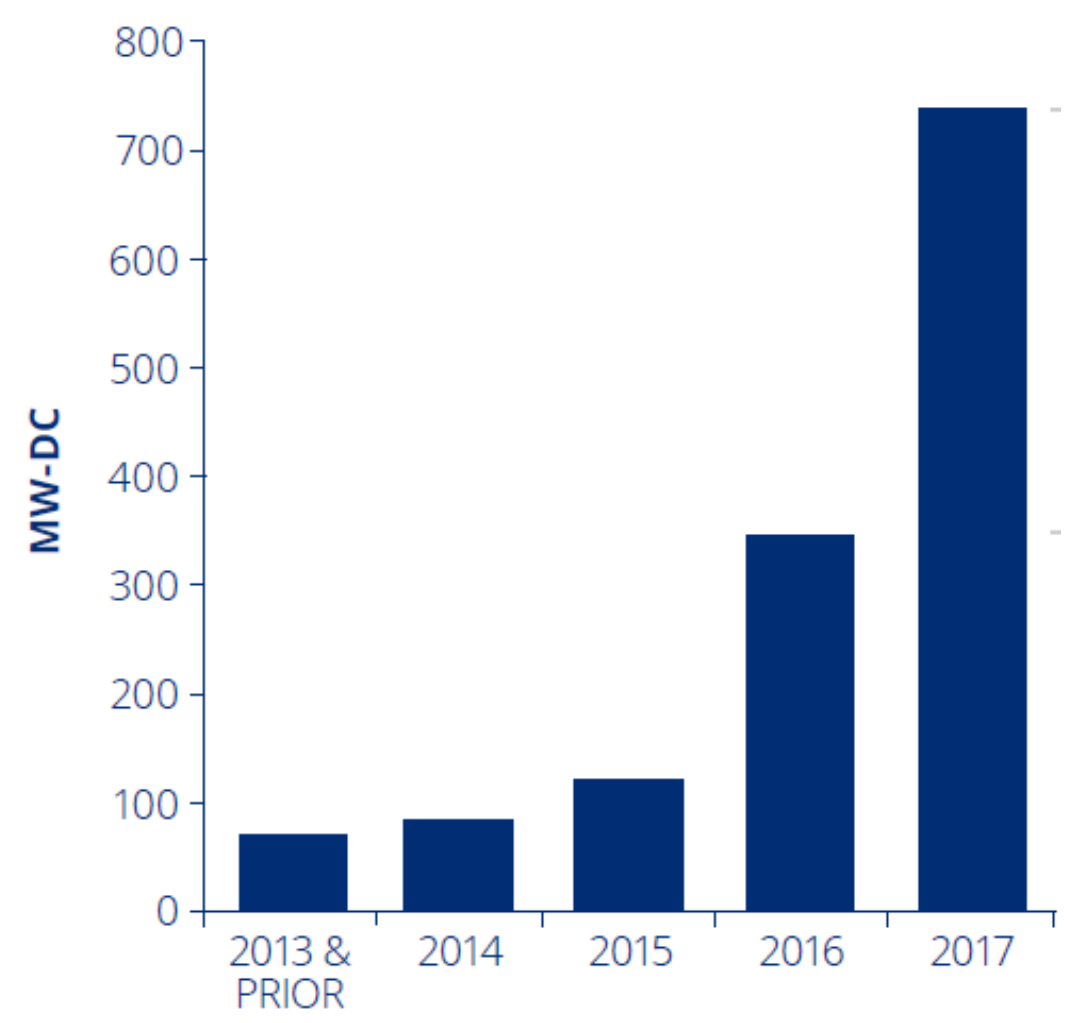

- SEPA estimates that in 2017 the U.S. community solar market doubled, growing from $347 \mathrm{MW}-\mathrm{DC}$ to $737 \mathrm{MW}-\mathrm{DC}$.

- SEIA estimates an additional $167 \mathrm{MW}$-DC of community solar was added in Q1 2018.

- Only 229 of 3,000 utilities have community solar programs; therefore, there is tremendous market potential. 
U.S. PV Deployment: Number of Community Solar Projects by State, 2017

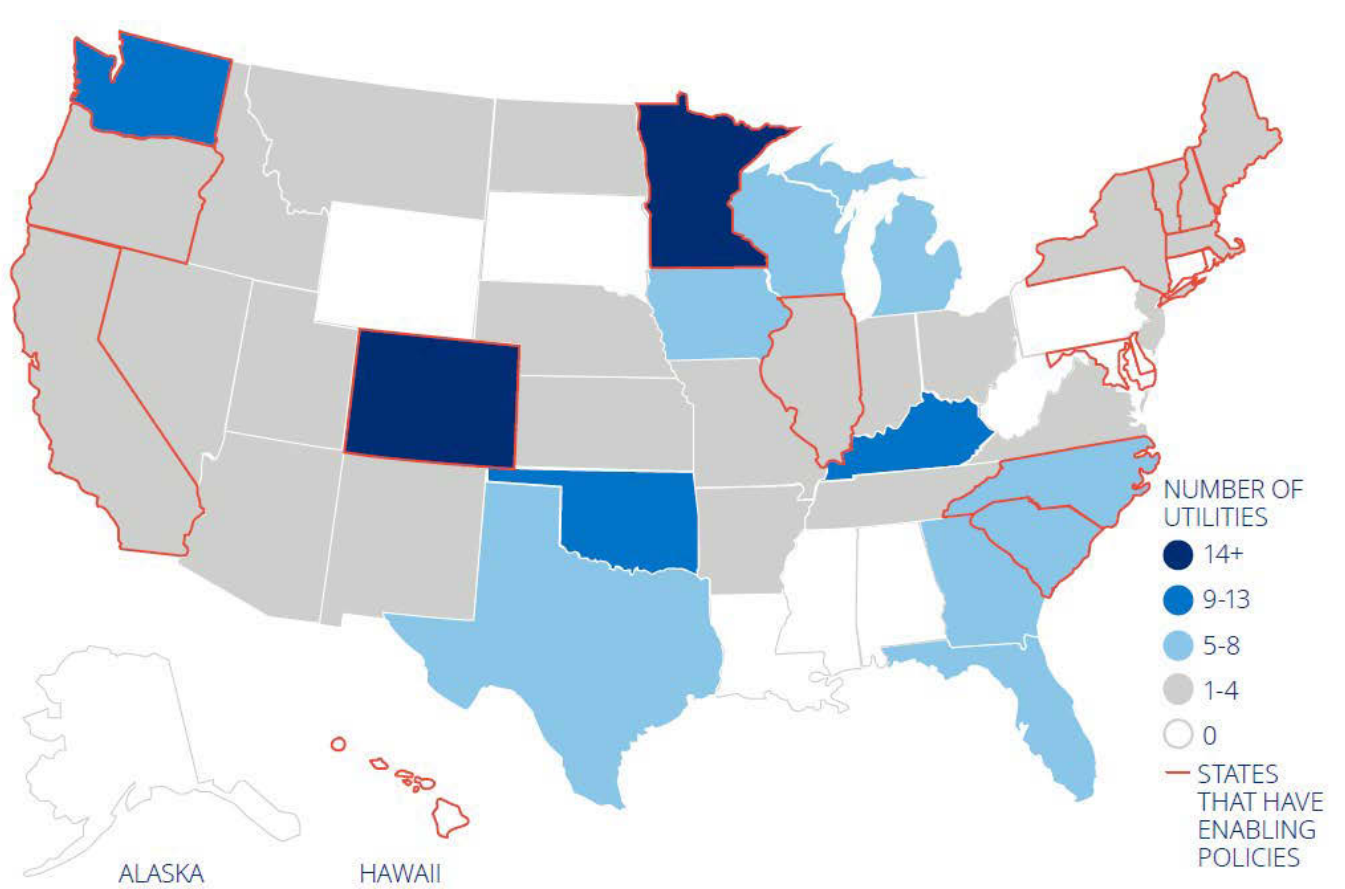

- At the end of 2017, there were $737 \mathrm{MW}-\mathrm{DC}$ of installed community solar.

- $542 \mathrm{MW}-\mathrm{DC}$ were located in 17 states (and D.C.) with community solar enabling policies

- 83 individual programs.

- 70\% of capacity managed by utilities.

- $195 \mathrm{MW}-\mathrm{DC}$ were in states without enabling policies.

- 146 individual programs.

- $95 \%$ of capacity managed by utilities. 
U.S. PV Deployment: U.S. Energy

\section{Storage Installations by Market Segment}

- The United States installed approximately 44 MW-AC (126 MWh) of energy storage onto the electric grid in Q1 2018.

- In 2017, $6 \%$ of non-residential PV systems and $1 \%$ of residential PV systems were paired with storage.

- GTM Research expected $24 \%$ of distributed PV to be paired with storage by 2024 .

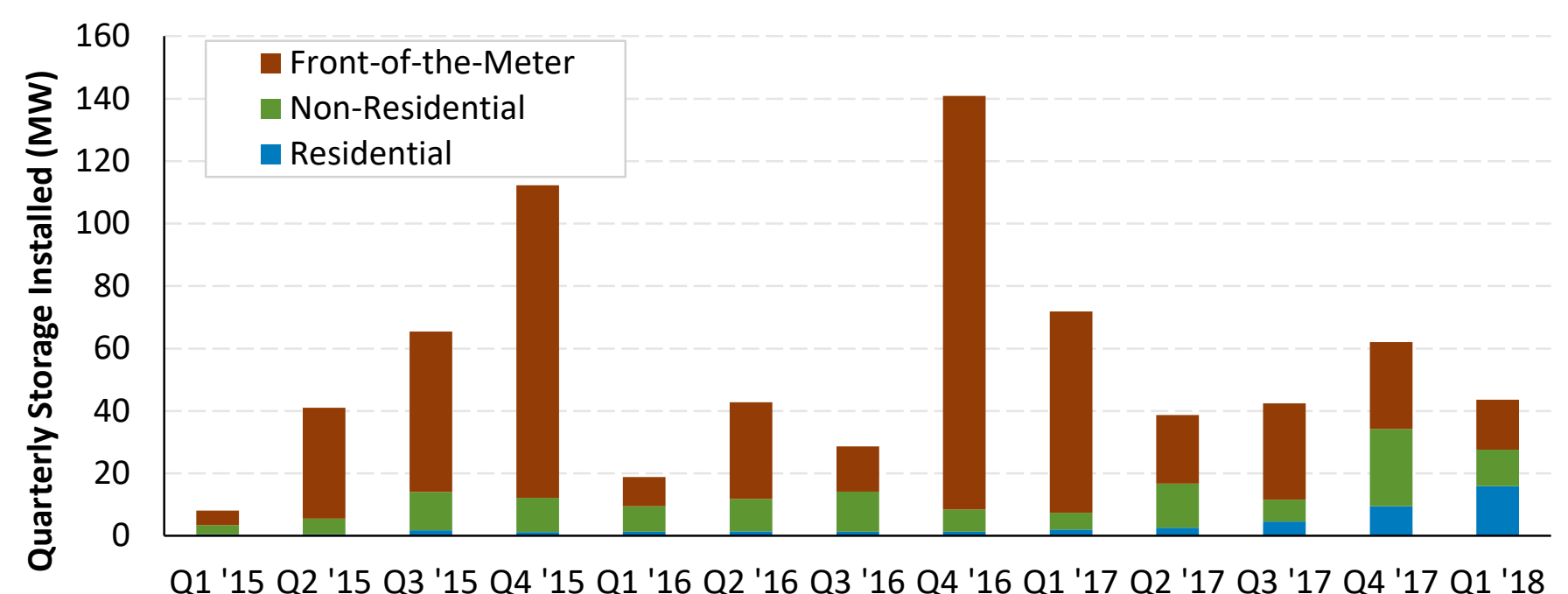

- Similar to the other electric technologies, largescale storage installations vary dramatically each quarter (typically with a large fourth quarter), while the residential market has a less volatile installation pattern.

- That said, in Q1 2018 the residential storage market grew by a factor of $7, \mathrm{y} / \mathrm{y}$. 


\section{U.S. PV Deployment: Average Lithium-ion Battery Pack Price (2010-2017)}

- Beyond variable generation driving demand, a large reason for the increase in storage deployment is the dramatic decline in battery pack pricing.

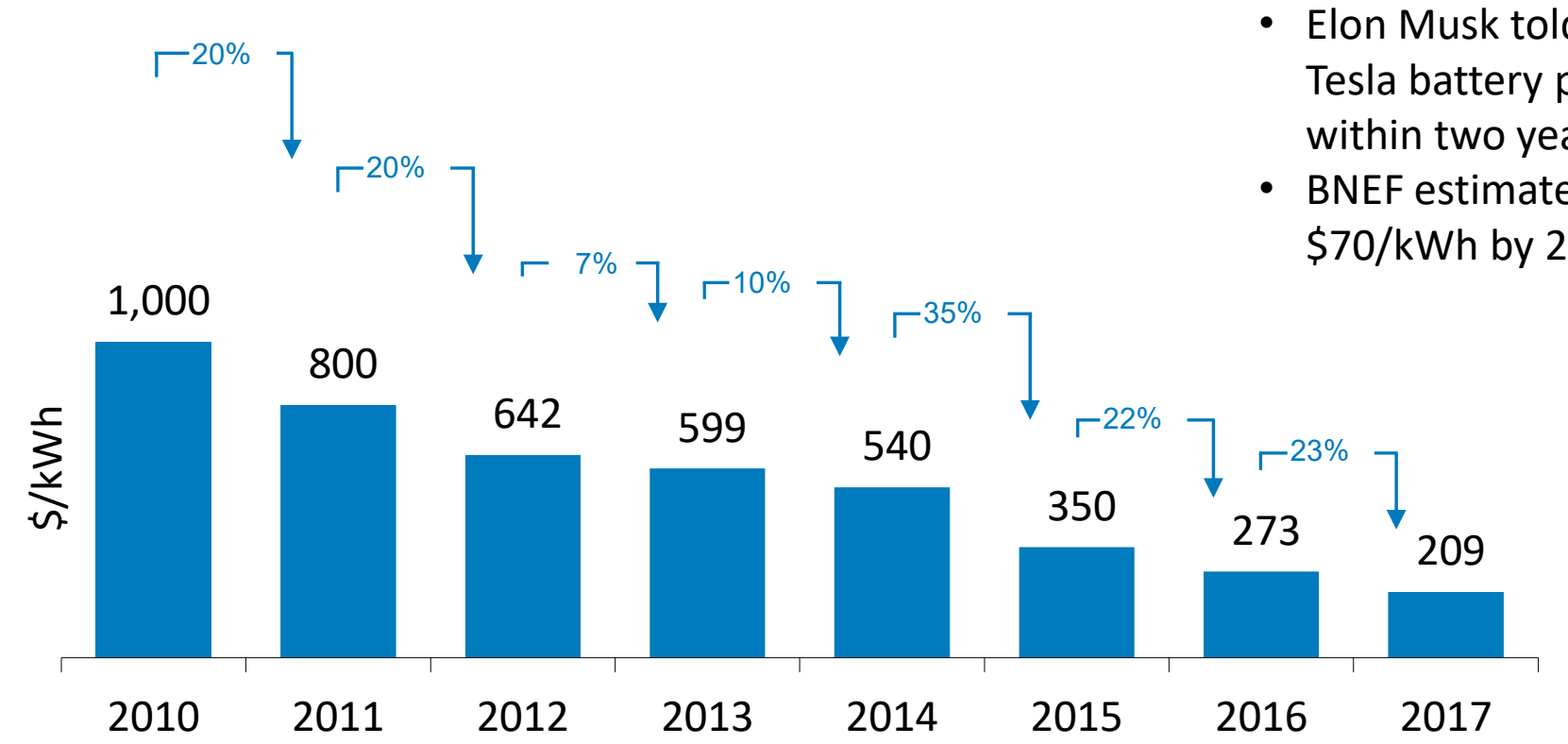

- From 2010 to 2017, average battery pack prices dropped $79 \%$.

- From 2016 to 2017, alone, prices dropped 23\%.

Elon Musk told shareholders in June he expects Tesla battery packs to cost less than $\$ 100 / \mathrm{kWh}$

BNEF estimates battery pack prices will reach 030. 


\section{U.S. PV Deployment: States with}

\section{Energy Storage Mandates}

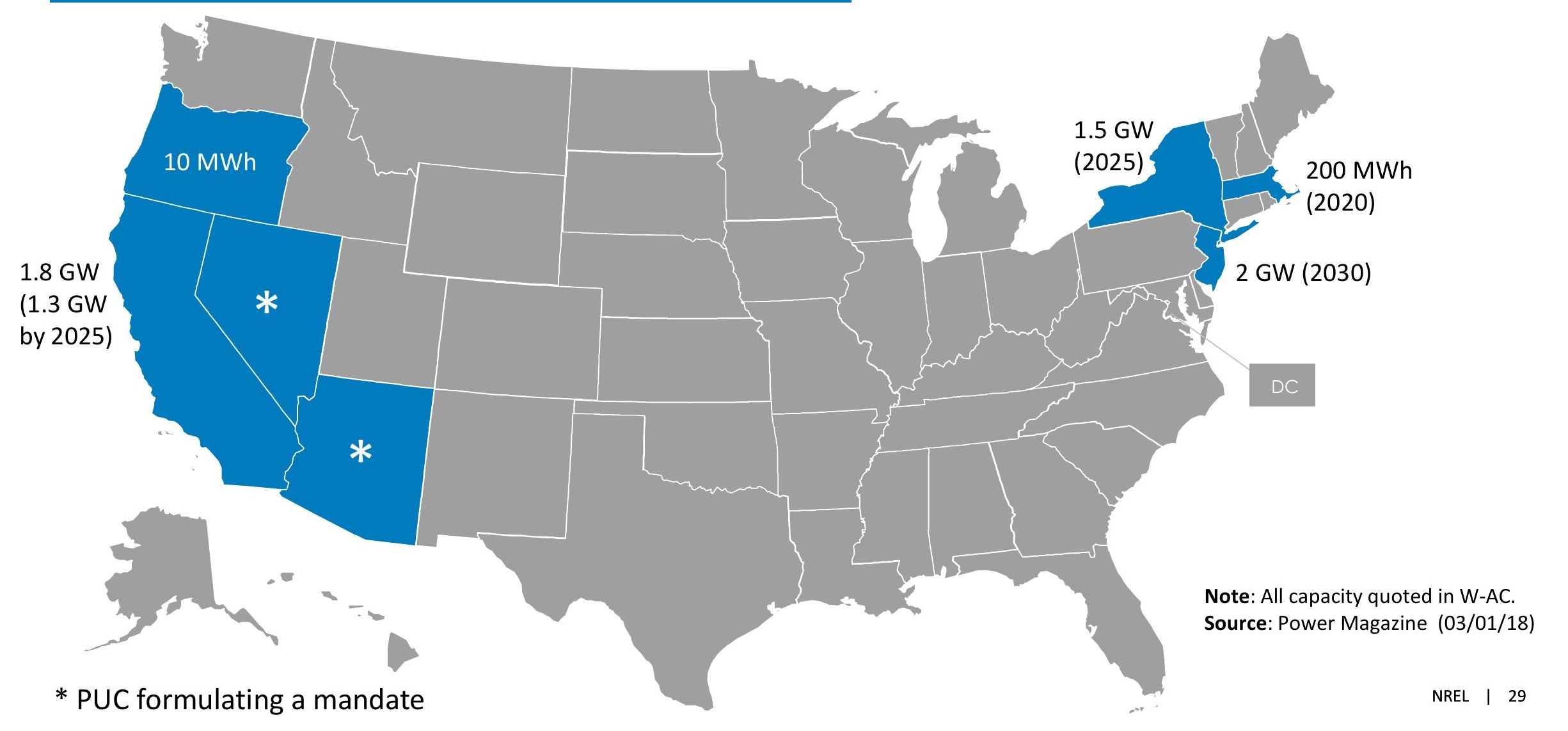


U.S. PV Deployment: Tesla, Vivint Solar, and Sunrun

\section{Residential Market Share}

- From Q1 2017 to Q1 2018 Tesla, Vivint, and Sunrun combined installations shrank $29 \%$, while the remainder of the market grew $18 \%$.

- Since Q4 2017, direct sales have represented the majority of Tesla's installations. Sunrun and Vivint continue to install mostly leased or PPA systems.

- When Tesla purchased SolarCity, it shifted strategy from sales growth to profitability. In its Q1 2018 letter to investors, Tesla stated their solar business has been slightly cash flow positive since the beginning of 2017 and it expects to improve significantly towards the second half of this year.

- Tesla shuttered sales channels and market segments that were unprofitable

- A significant portion of the Tesla customer base is waiting for Powerwall before installing solar panels, and Tesla is prioritizing Powerwall's bundled with solar.

- Tesla and Sunrun are also expanding product offerings through PV+storage.

- Tesla has installed over $1 \mathrm{GWh}$ of storage globally; $373 \mathrm{MWh}$ in Q1 2018 alone (129 MWh of that from an Australian installation).

- $20 \%$ of Sunrun's California customers opted for their solar+storage option; the company also launched its storage option in Hawaii, Arizona, Massachusetts, Nevada, and New York.
Residential Installs (MW-DC)

800

700

600

500

400

300

200

100

0

Q1 Q2 Q3 Q4 Q1 Q2 Q3 Q4 Q1 Q2 Q3 Q4 Q1 Q2 Q3 Q4 Q1 '14 '14 '14 '14 '15 '15 '15 '15 '16 '16 '16 '16 '17 '17 '17 '

\section{Percent of Direct Sales / Loans}

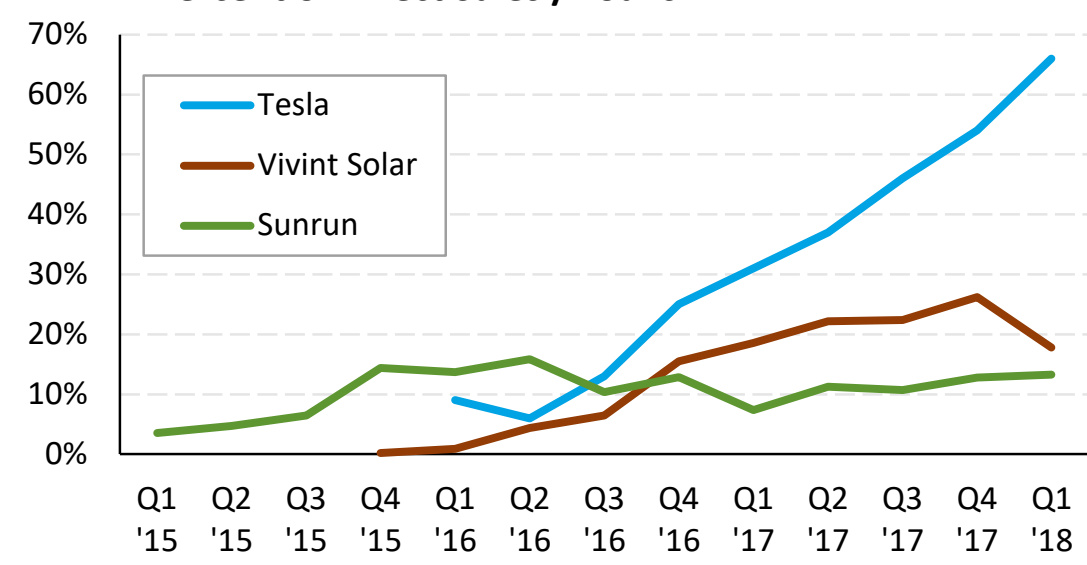




\section{U.S. PV Deployment: BIPV and Bifacial modules in the United States}

\section{California Installs (kW)}

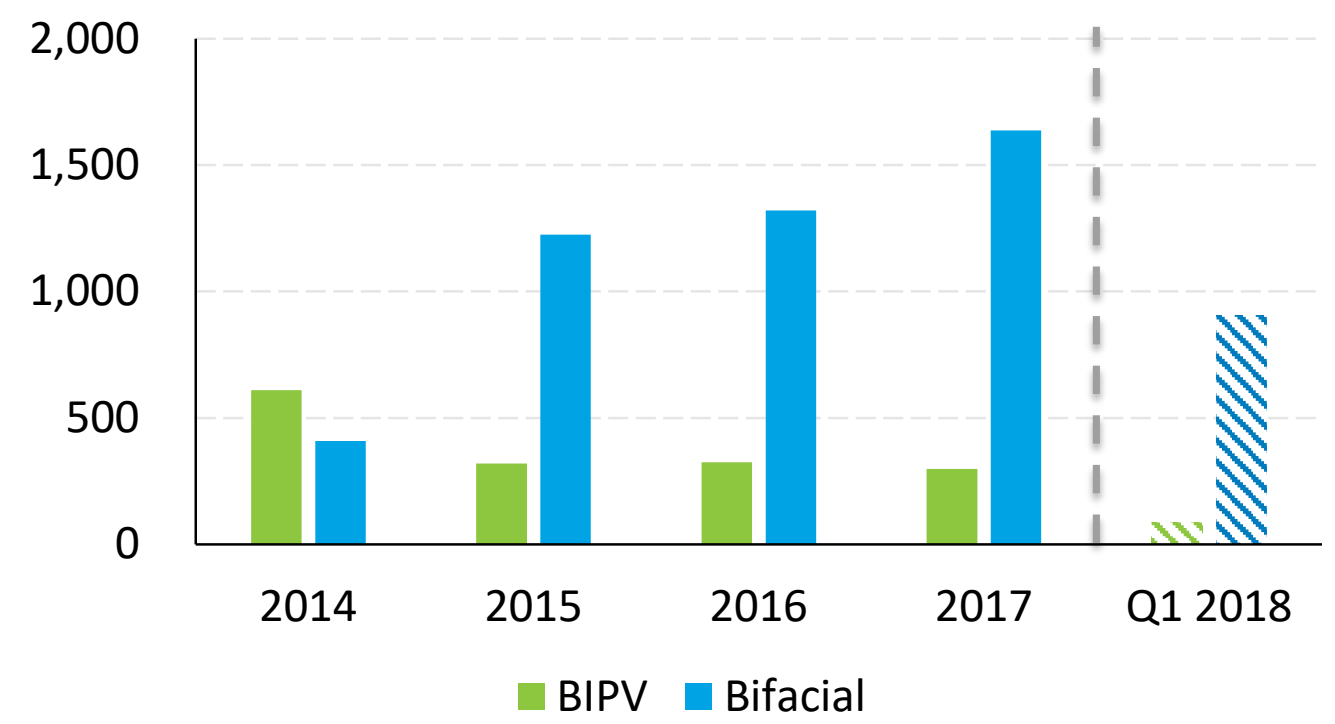

- California installed 1.6 MW-DC of BIPV and 5.5 MW-DC of bifacial modules from 2014 to the first quarter of 2018 in the DPV market.

- All of the bifacial modules in the California distributed market were installed since 2014 compared to $12 \%$ for BIPV.

- These systems represented $0.04 \%$ and $0.12 \%$ of total installs over that time.

- Bifacial modules are likely to gain more traction with larger, ground-mounted systems, as more insolation bounces off the ground under PV systems than under rooftop applications. 
1 Federal and State Updates

\section{Global Solar Deployment}

\section{U.S. PV Deployment}

\section{PV System Pricing}

\section{Global Manufacturing}

6 Component Pricing
- From H1 2017 to H1 2018, the median reported PV system price in Arizona, California, Connecticut, Massachusetts, and New York fell $5 \%$ to $\$ 4.06 / \mathrm{W}$ for systems $2.5 \mathrm{~kW}-10 \mathrm{~kW}$ and increased $7 \%$ to $\$ 2.98 / \mathrm{W}$ for systems $100 \mathrm{~kW}-$ $500 \mathrm{~kW}$.

- In Q1 2018, totals costs for Vivint- and Sunrunbuilt systems were between $\$ 2.95 / \mathrm{W}$ and $\$ 3.25 / \mathrm{W}$. 


\section{System Pricing From Select States}

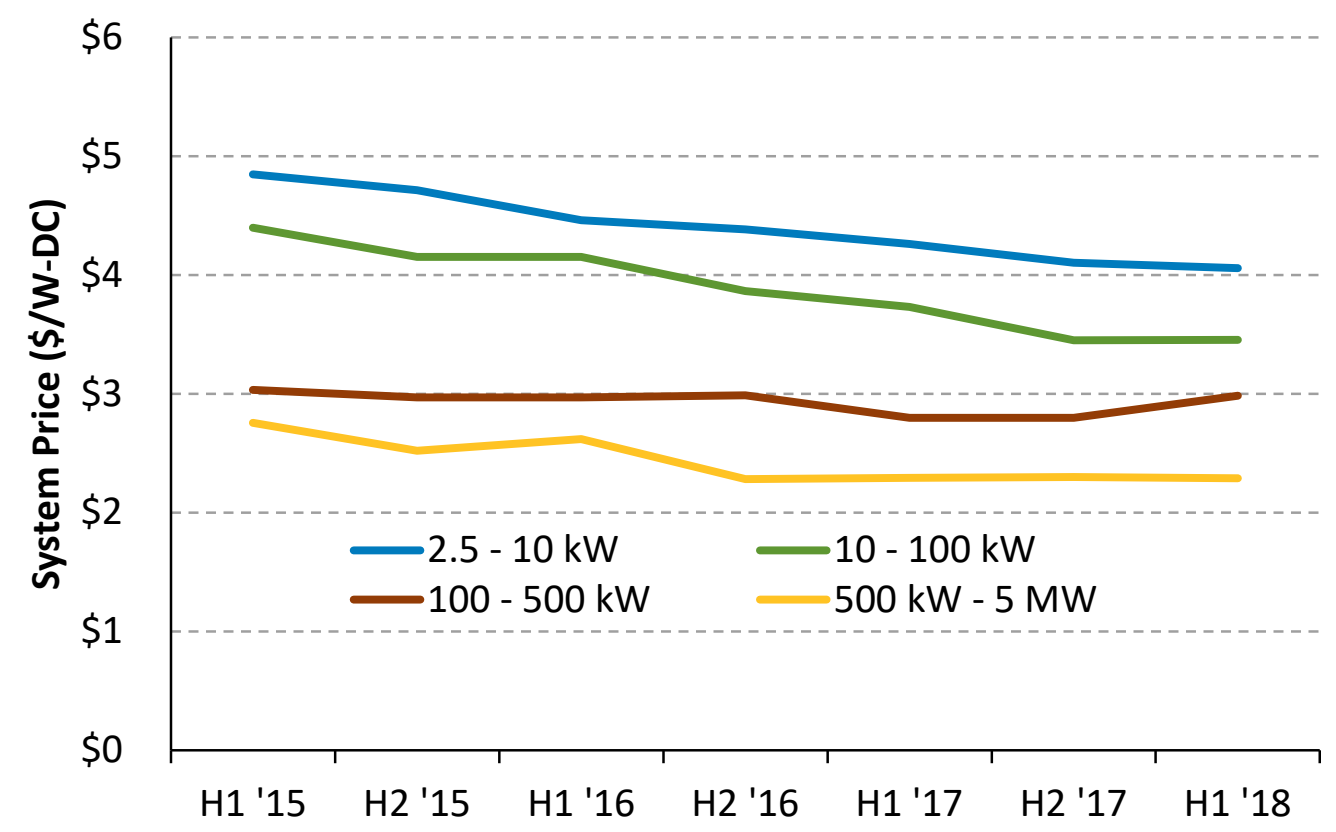

Preliminary H1 2018 MW-DC: AZ (75), CA (259), CT (14), MA (79), NY (127)

Note: CA NEM data have only been reported through April 2018. System prices above $\$ 10 / W$ and below $\$ 1 / \mathrm{W}$ were removed from the data set.

Sources: CA NEM database; MA SREC program; Arizona Public Services and Salt River Project; CT Green Bank; NYSERDA. All programs accessed 07/31/2018.
Based on preliminary data for $\mathrm{H} 1$ 2018, from H1 2017 to $\mathrm{H} 12018$, the median reported PV system price in Arizona, California, Connecticut, Massachusetts, and New York:

- Fell $5 \%$ to $\$ 4.06 / \mathrm{W}$ for systems $2.5 \mathrm{~kW}-10 \mathrm{~kW}$

- Fell $7 \%$ to $\$ 3.45 / \mathrm{W}$ for systems $10 \mathrm{~kW}-100 \mathrm{~kW}$

- Increased $7 \%$ to $\$ 2.98 / \mathrm{W}$ for systems $100 \mathrm{~kW}-500 \mathrm{~kW}$

- Were flat at $\$ 2.29 / W$ for systems $500 \mathrm{~kW}-5 \mathrm{MW}$. 
PV System Pricing:

System Pricing from

\section{Select States, H1 2018}

- In addition to price differences based on system size, there is also variation between states and within individual markets.
- Based on initial data in H1 2018, the median price of a small system in Arizona was about $21 \%$ less than the median price in California.

- In $\mathrm{H} 12018$, the $20^{\text {th }}$ and $80^{\text {th }}$ percentile prices in California for a small system were $\$ 3.47 / \mathrm{W}$ and $\$ 5.43 / \mathrm{W}$ respectively.
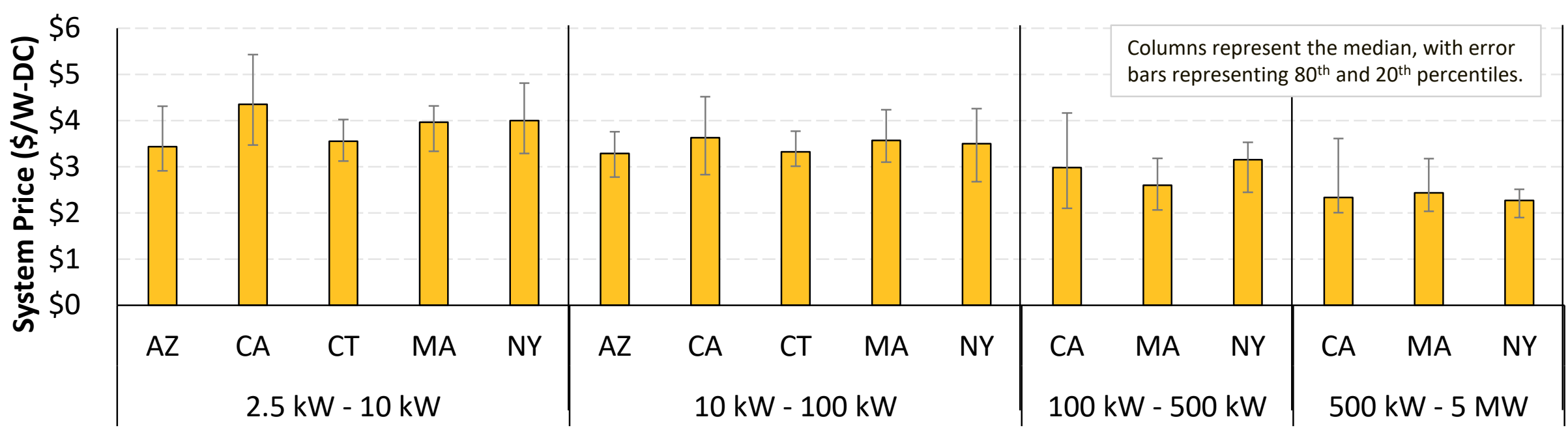

Preliminary H1 2018 MW-DC: AZ (75), CA (259), CT (14), MA (79), NY (127)

Note: CA NEM data have only been reported through April 2018. System prices above $\$ 10 / \mathrm{W}$ and below $\$ 1 / \mathrm{W}$ were removed from the data set.

Sources: CA NEM database; MA SREC program; Arizona Public Services and Salt River Project; CT Green Bank; 
PV System Pricing:

BIPV and Bifacial modules

in the United States

\section{Residential ASP (\$/W)}

$\$ 7$
$\$ 6$
$\$ 5$
$\$ 4$
$\$ 3$
$\$ 2$
$\$ 1$
$\$ 0$

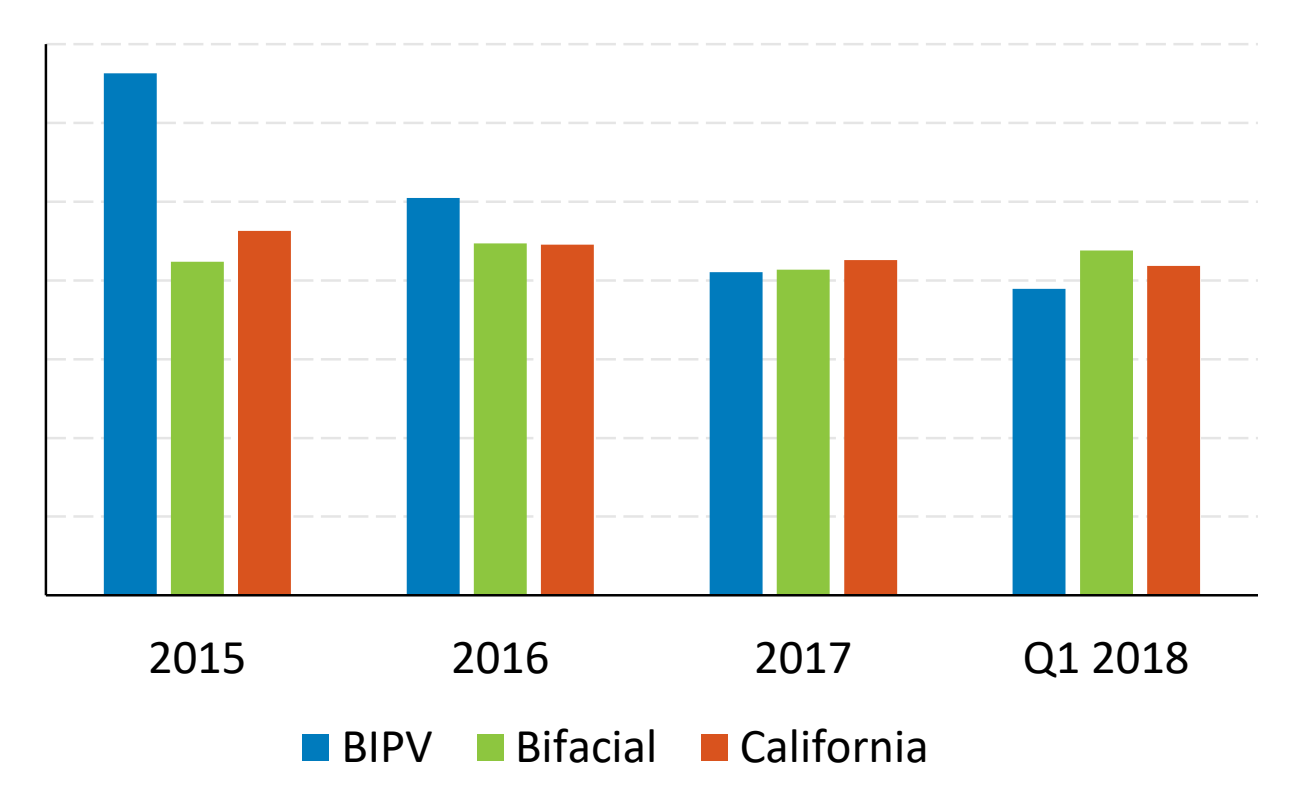

- Since 2017, residential BIPV and bifacial systems have reported similar pricing as the overall market.

- In the residential market, modules are a relatively small part of the overall cost.

- Despite reporting similar pricing as other products in 2017 and the first quarter of 2018, BIPV installations shrank. 
PV System Pricing:

New York Community Solar System Pricing (2016-2018)

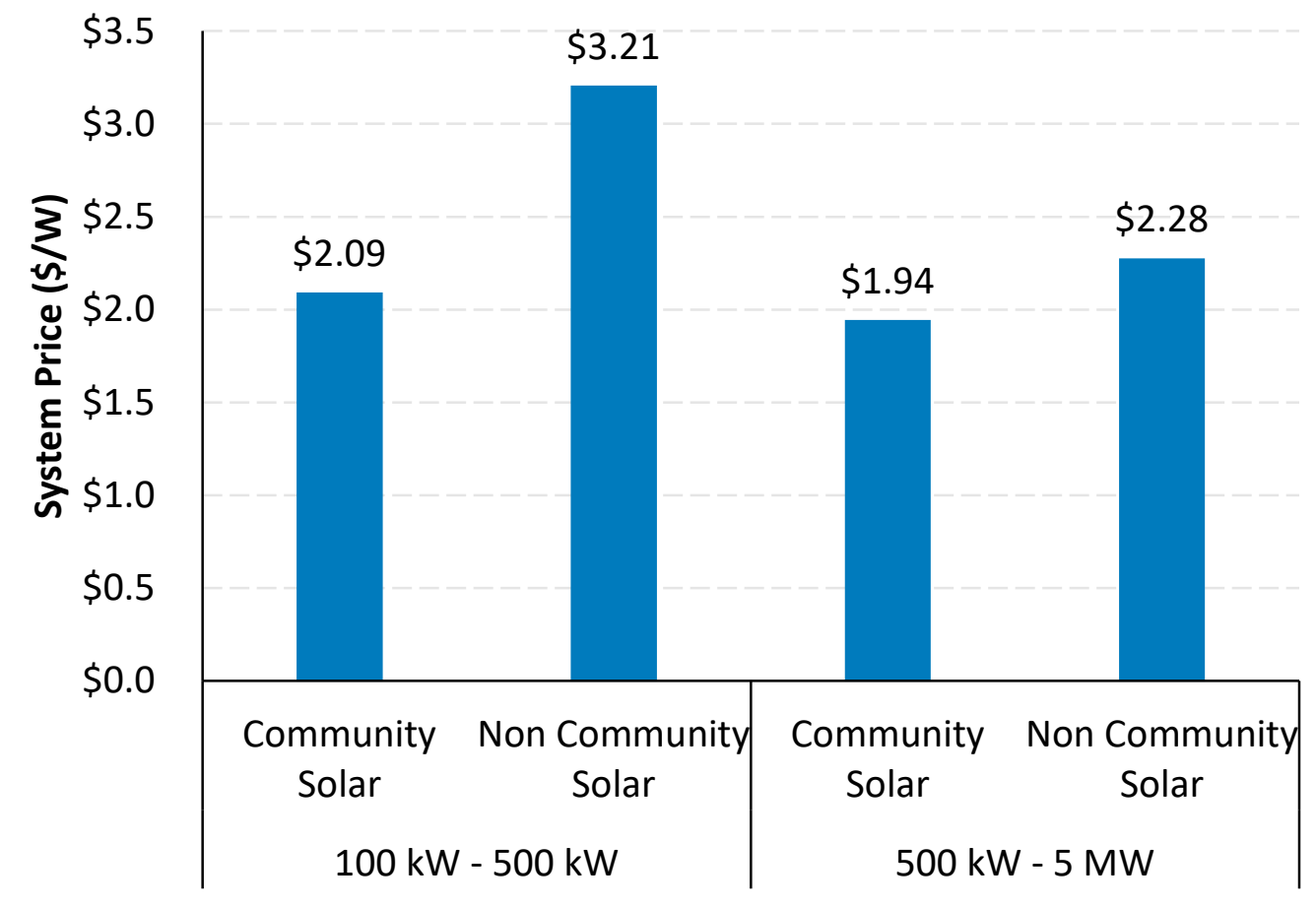

- Since the start of 2016,16 community solar projects have reported pricing in New York, with average rates substantially lower than other PV systems in New York of comparable size. 
PV System Pricing:

\section{Vivint Solar and Sunrun \\ Cost and Value}

- For the past two years, Vivint Solar and Sunrun total system costs have remained relatively flat.

- Vivint Solar- and Sunrun-built installation costs bottomed in Q3 2017 at $\$ 1.82 / \mathrm{W}$ and $\$ 1.72 / \mathrm{W}$ respectively. As of Q1 2018 they were $6 \%-12 \%$ higher.

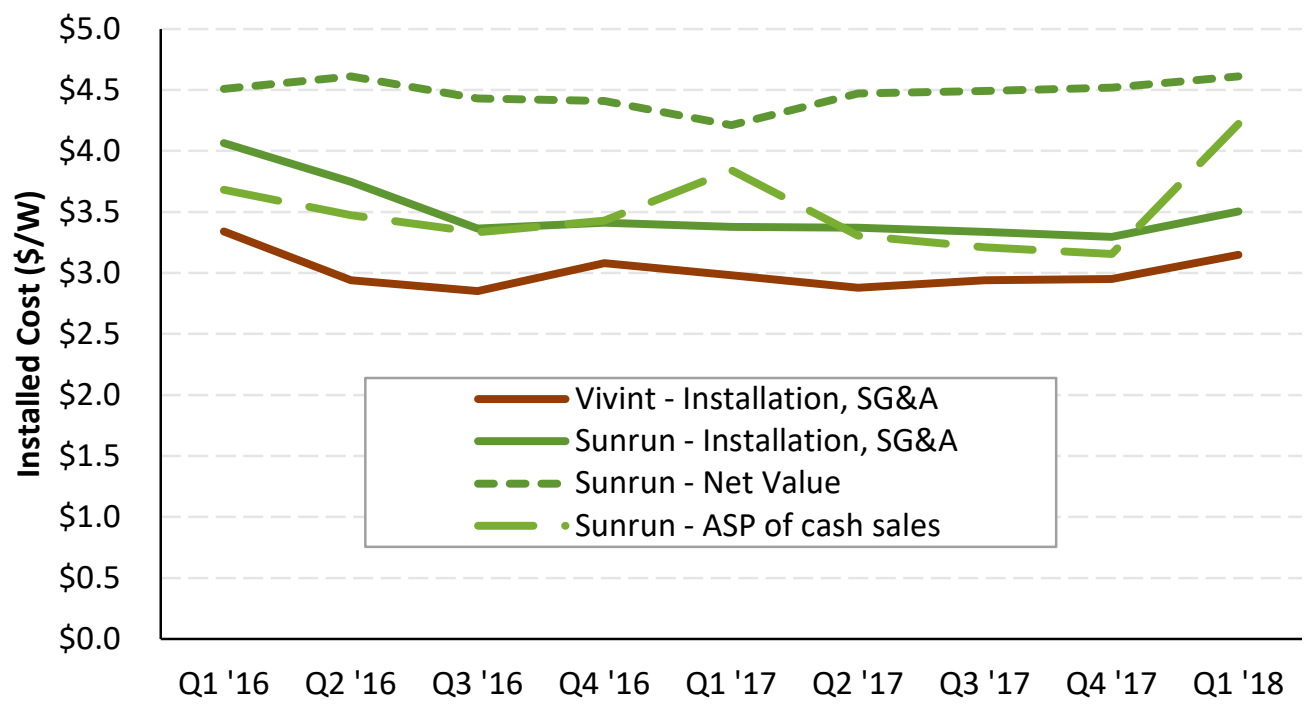

Sources: Corporate filings
- Sunrun reported the average selling price of their cashpurchased systems to be generally declining but reported a large increase in Q1 2018. No reason was given.

- In Q1 2018, total costs for Vivint- and Sunrun-built systems were approximately $\$ 3 / \mathrm{W}$.

- Sunrun still reports a PV system value of approximately $\$ 4.5 / \mathrm{W}$.

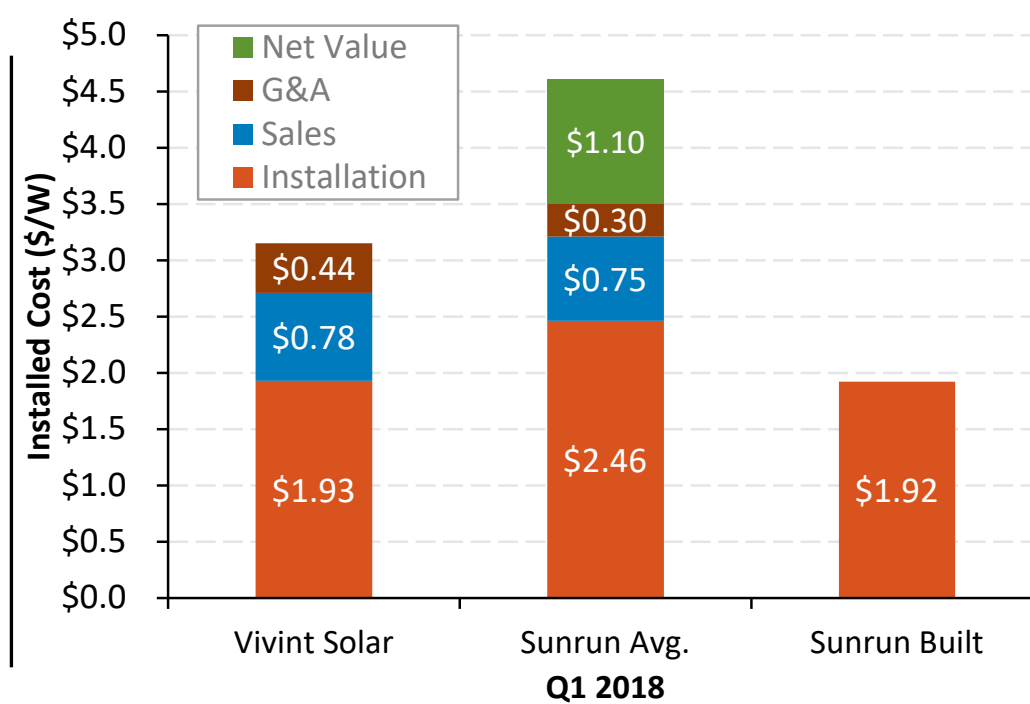




\section{Federal and State Updates}

\section{Global PV Deployment}

\section{U.S. PV Deployment}

\section{PV System Pricing}

5 Global Manufacturing

6 Component Pricing 7 Market Activity
- While falling module prices appears to have caught many companies off-guard in 2016, as of Q1 2018, those still operating appear to have made adjustments to maintain corporate margins.

- Most PV manufacturers accrue $1 \%$ of revenue in warranty provision costs to cover future warranties; however from 2015 to 2017, leading manufacturers only spent $0.3 \%-0.6 \%$ of total revenue to cover product warranties. 


\section{Global Manufacturing: Manufacturers' Shipments}

\section{Publicly Traded Cell/Module Manufacturers}

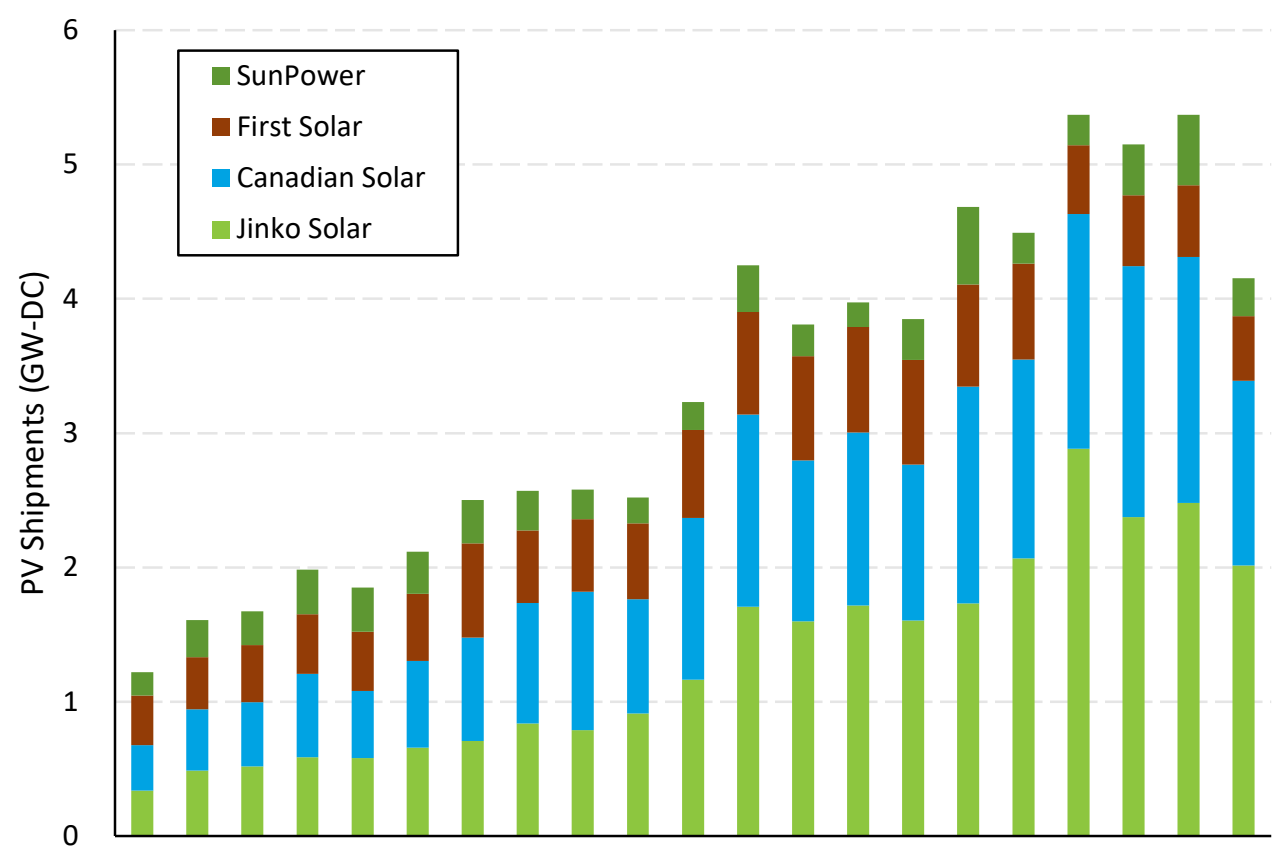

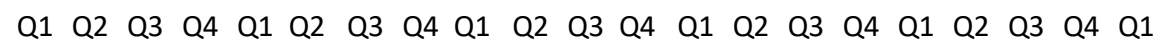

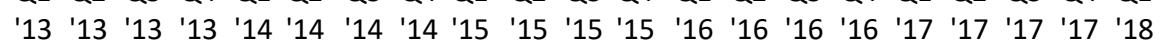

- In Q1 2018, these tracked companies shipped 4 GW-DC, a decrease of 8\% over Q1 2017.

- The slowing of growth in key markets, such as the United States and China has caused shipments to level off.

- Publicly available shipment data are not as representative of the total PV market as they once were. Since 2012, the following public, or formerly public companies, have either gone bankrupt (B), exited the industry $(E)$, become private $(P)$, or stopped reporting quarterly shipment data (S):

- Q Cells (B) - 2012

- Suntech (B) - 2013

- Sharp (E) - 2014

- Hanwha (S) - 2016

- Trina (P) - 2017

- ReneSola (E) - 2017

- Yingli (S) - 2018 (delisted from NYSE in June 2018)

- JA Solar (P) - 2018 (privatized in July 2018) 
Global Manufacturing:

\section{PV Manufacturers'}

\section{Warranty Costs}

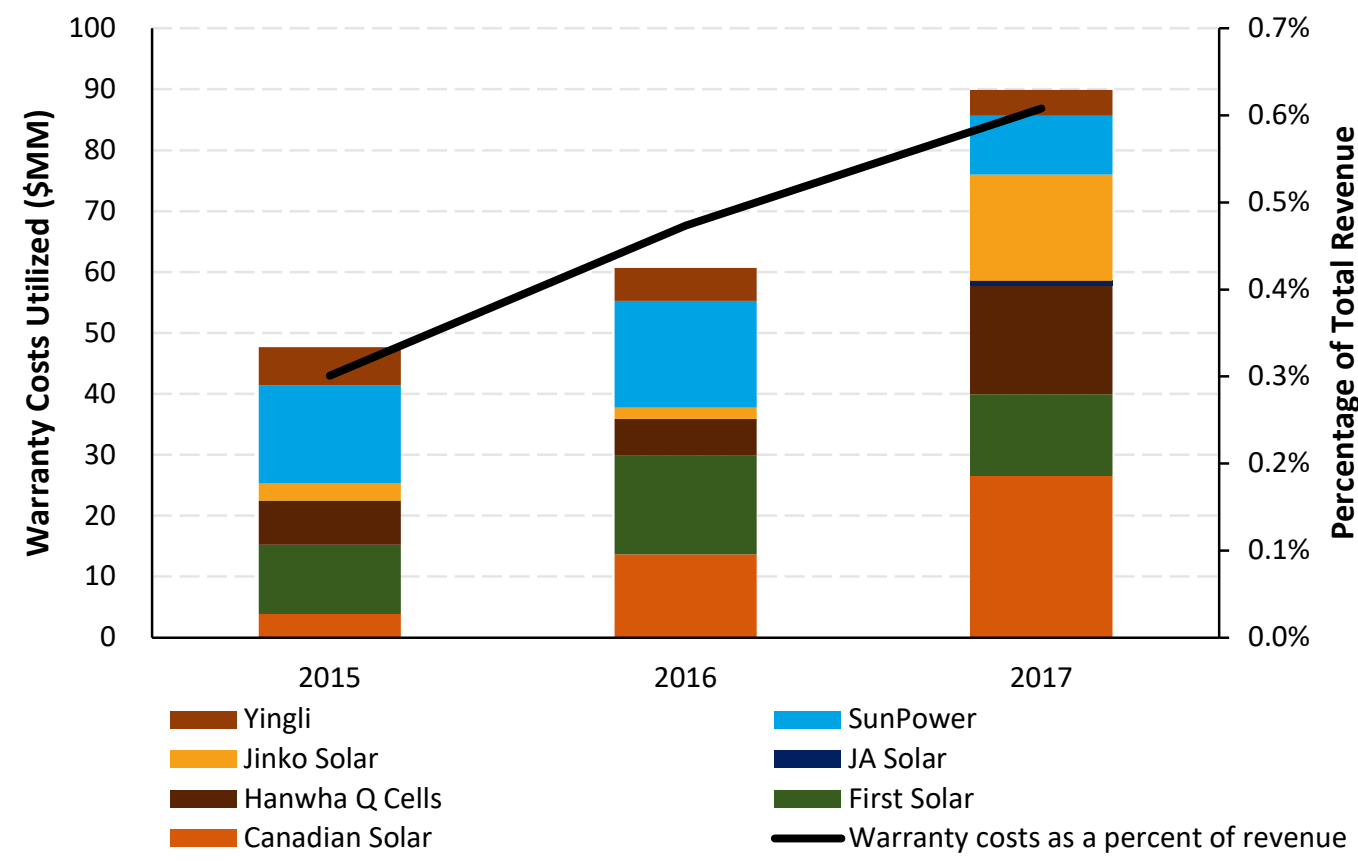

- In 2017, the following seven PV manufacturers spent approximately $\$ 90$ million to cover product warranties, or approximately $0.6 \%$ of total revenue.

- Most PV manufacturers accrue $1 \%$ of revenue in warranty provision costs to cover future warranties. At the end of 2017, these seven manufacturers had approximately $\$ 0.8$ billion in accrued warranties to cover future claims.

- Most manufacturers also pay insurance to cover warranty claims.

- Warranty provisions vary, but most manufacturers guarantee a minimum peak power, declining no more than $2 \%-3 \%$ in the first year and then $0.25 \%-0.7 \%$ per year thereafter, for 25-30 years. Manufacturers typically also have a 10 -year warranty for defects in materials and workmanship. 


\section{Federal and State Updates}

\section{Global PV Deployment}

\section{U.S. PV Deployment}

\section{$4 \quad$ PV System Pricing}

\section{Global Manufacturing}

6 Component Pricing

7 Market Activity
- Module, cell, and wafer prices have dropped since the beginning of the year, but they accelerated in June and July after China terminated subsidies on new utility-scale PV projects in 2018 and reduced its FIT. In July, global module ASP was reported to be $\$ 0.26 / \mathrm{W}$.

- Modules sold in the United States in Q1 2018 were 53\% higher than the global average.

- In Q1 2018, JinkoSolar reported in-house module costs of $\$ 0.31 / \mathrm{W}$. 


\section{Component Pricing: PV Value Chain Spot Pricing}

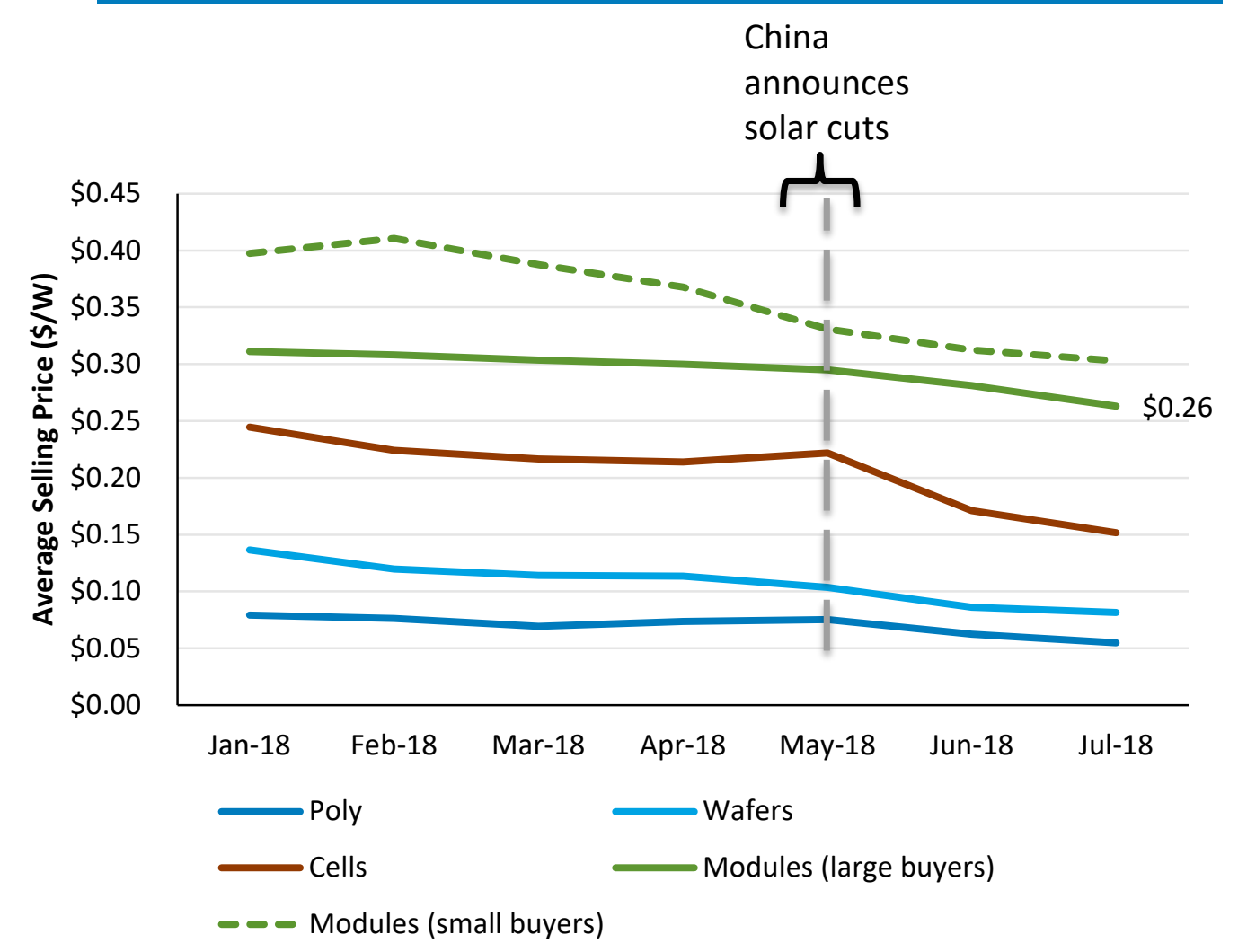

- Module, cell, and wafer prices have dropped since the beginning of the year, but they accelerated in June and July after China's announcement on May 31, terminating subsidies on new utility-scale PV projects in 2018 and reducing its FIT.

- Polysilicon prices averaged $\$ 15.5 / \mathrm{kg}$ at the end of May 2018 and by the end of July were $\$ 11.5 / \mathrm{kg}-\mathrm{a}$ record low. 
Component Pricing:

Module Average Selling Price-

\section{Global vs. U.S.}

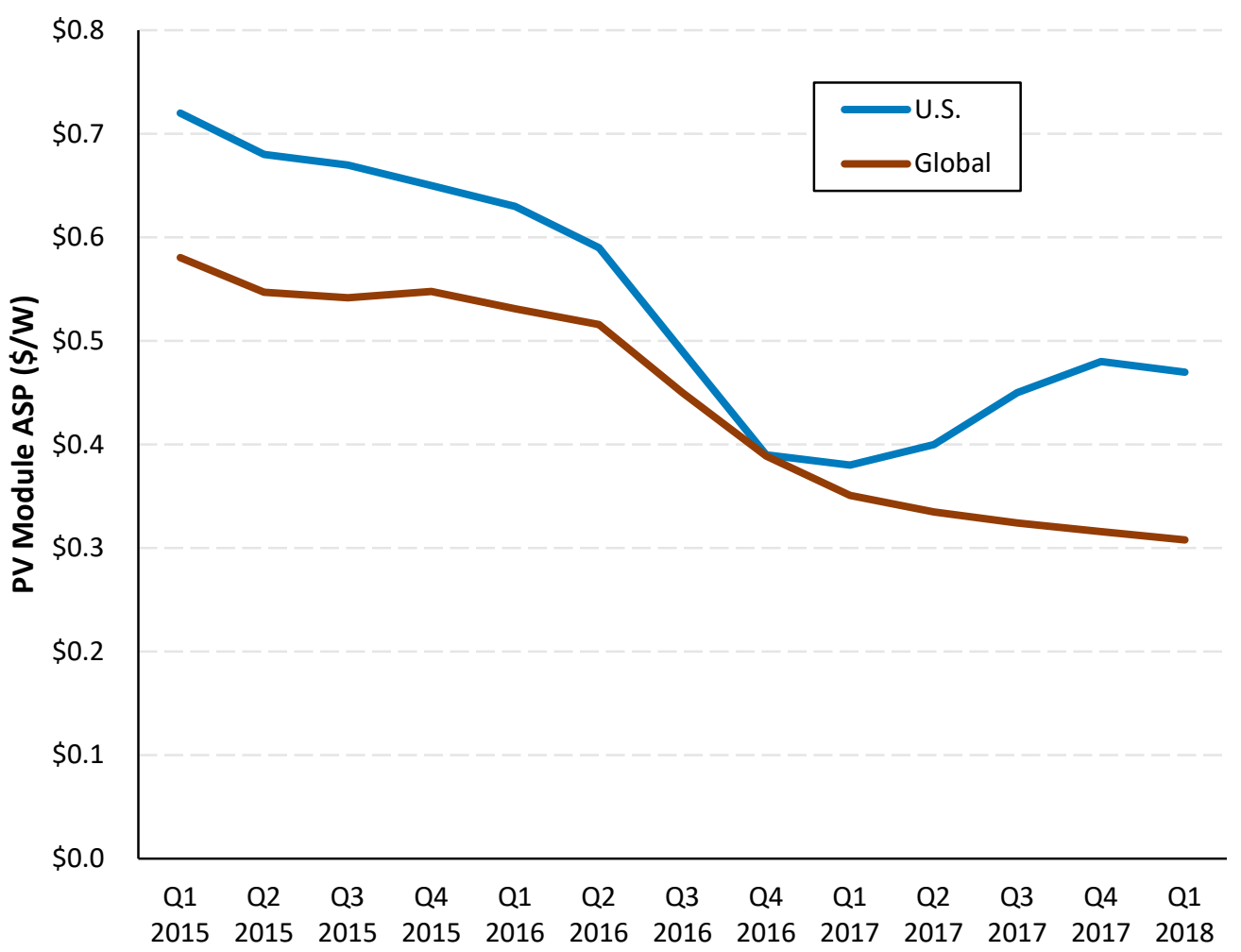

- In Q1 2018, U.S. module prices began to fall again but were still trading at a significant premium over global module ASP.

- Modules sold in the United States in Q1 2018 were 24\% higher than modules sold in the United States in Q1 2017 and $53 \%$ higher than the global average.

- Bank of America reported further module price declines in the United States in Q2 2018 to around \$0.44/W. 
Component Pricing: JinkoSolar Reported

\section{In-house Module Costs}

In Q1 2018, JinkoSolar reported in-house module costs of $\$ 0.31 / \mathrm{W}$.

JinkoSolar has reported approximately the same in-house costs since Q4 2016 and approximately the same polysilicon costs $(\$ 0.07 / \mathrm{W})$ since Q4 2015.

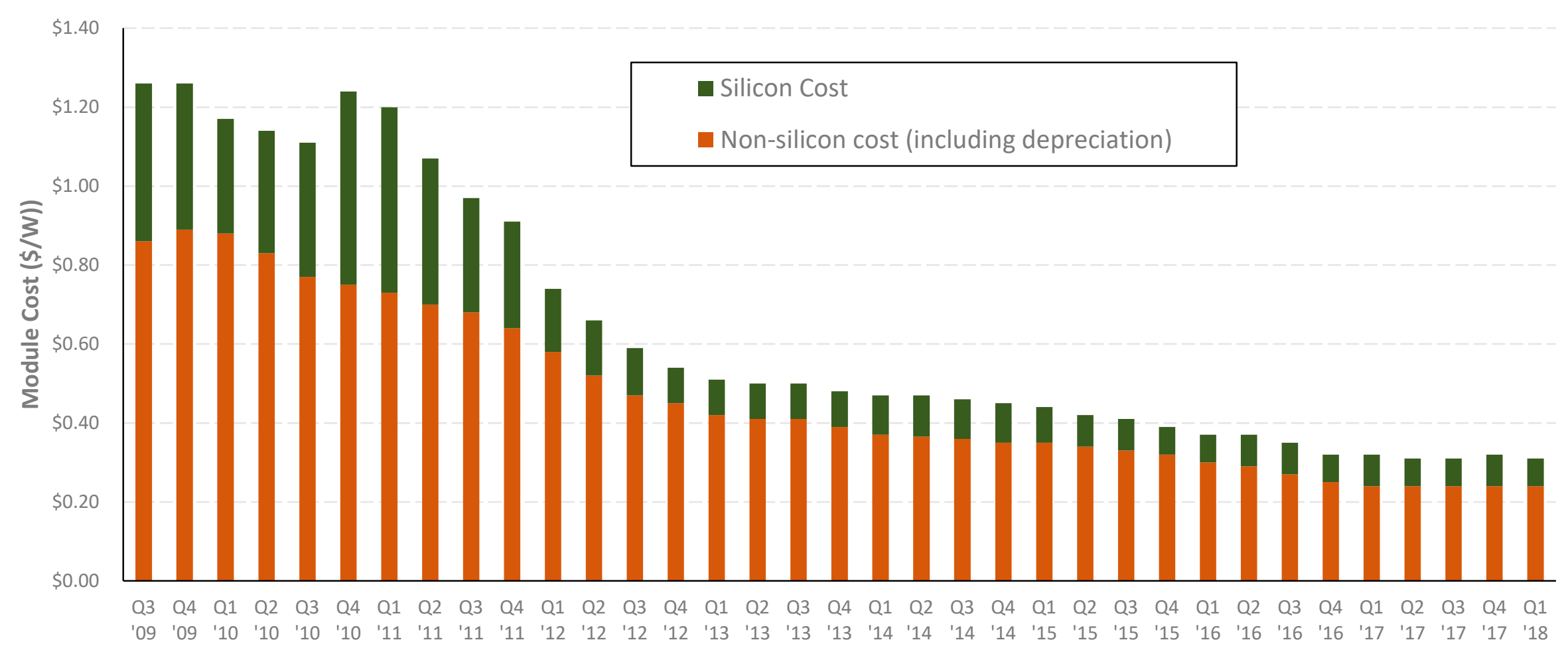

Sources: Company figures based on Q1 2018 (and previous) SEC filings by the respective companies; Deutsche Bank (07/18/17 (02/25/18). 


\section{Component Pricing: Inverter Pricing}

- Inverter prices dropped approximately $\$ 0.01 / \mathrm{W}$ in Q1 2018, down 7\% $\mathrm{y} / \mathrm{y}$ in the residential market and $15 \%-20 \%$ in the commercial and residential markets.

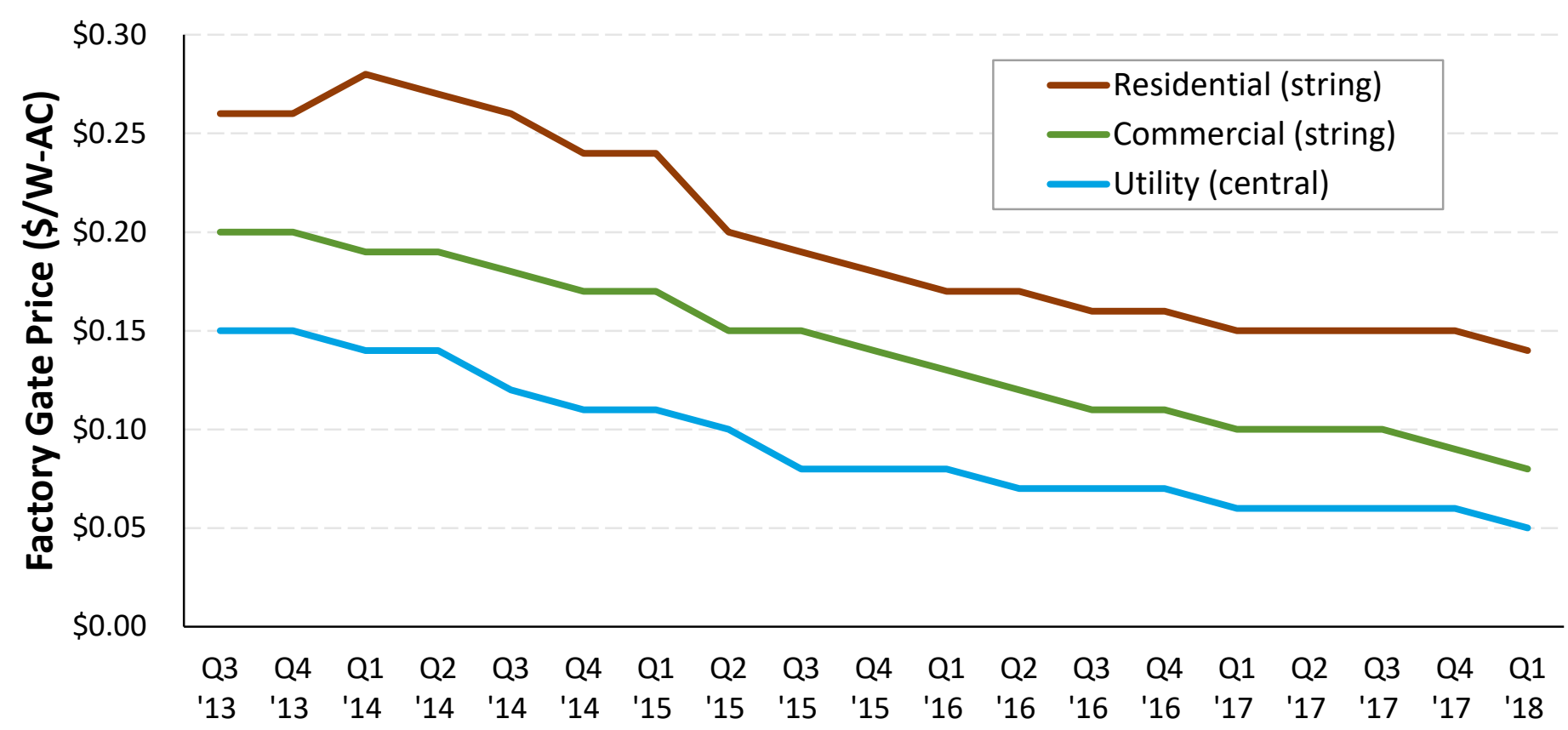


Component Pricing:

Enphase Microinverters and

\section{SolarEdge DC-Optimized Inverter Systems}

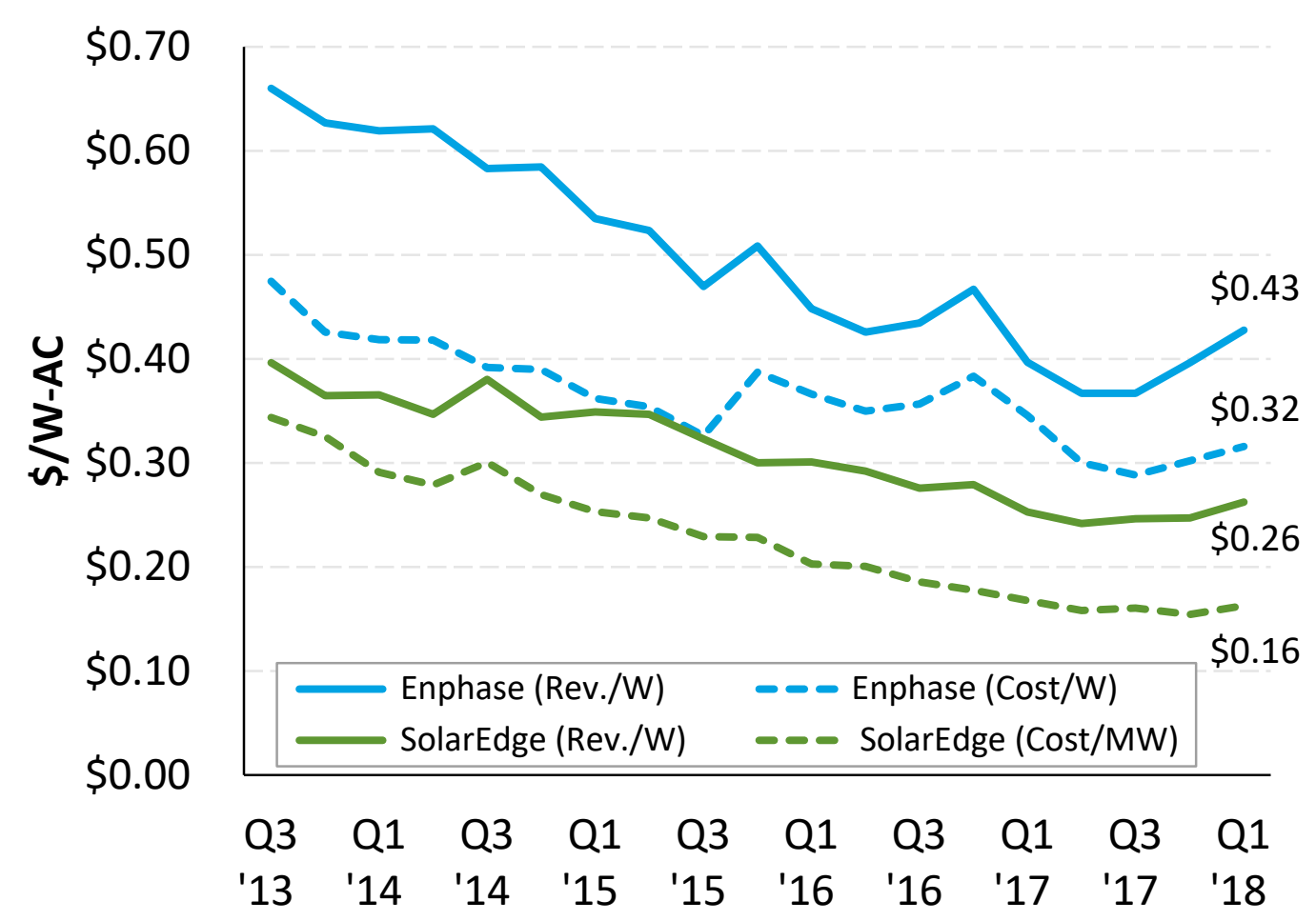

Note: Starting in Q2 2017 Enphase switched reporting shipments from W-AC to W-DC; we adjust these values using an ILR of 1.1. Sources: Corporate filings. Goldman Sachs (07/27/18).
- Module-level power electronics (MLPE) continue to have higher costs over string and centralized inverters, however they are also able to charge a price premium.

- In Q1 2018, Enphase recorded its highest gross margin since Q3 2015, and SolarEdge recorded its highest gross margin to-date.

- These companies have cut operating costs and are transitioning to more advanced technologies to better compete in this highly competitive marketplace.

- The largest PV inverter manufacturer in the world, Huawei, is launching a residential DCoptimized inverter system in Q3 2018, which is likely to significantly increase competition.

- Goldman Sachs announced Huawei was product-testing the product at key customer targets with Tier-1 adoption by year end. 


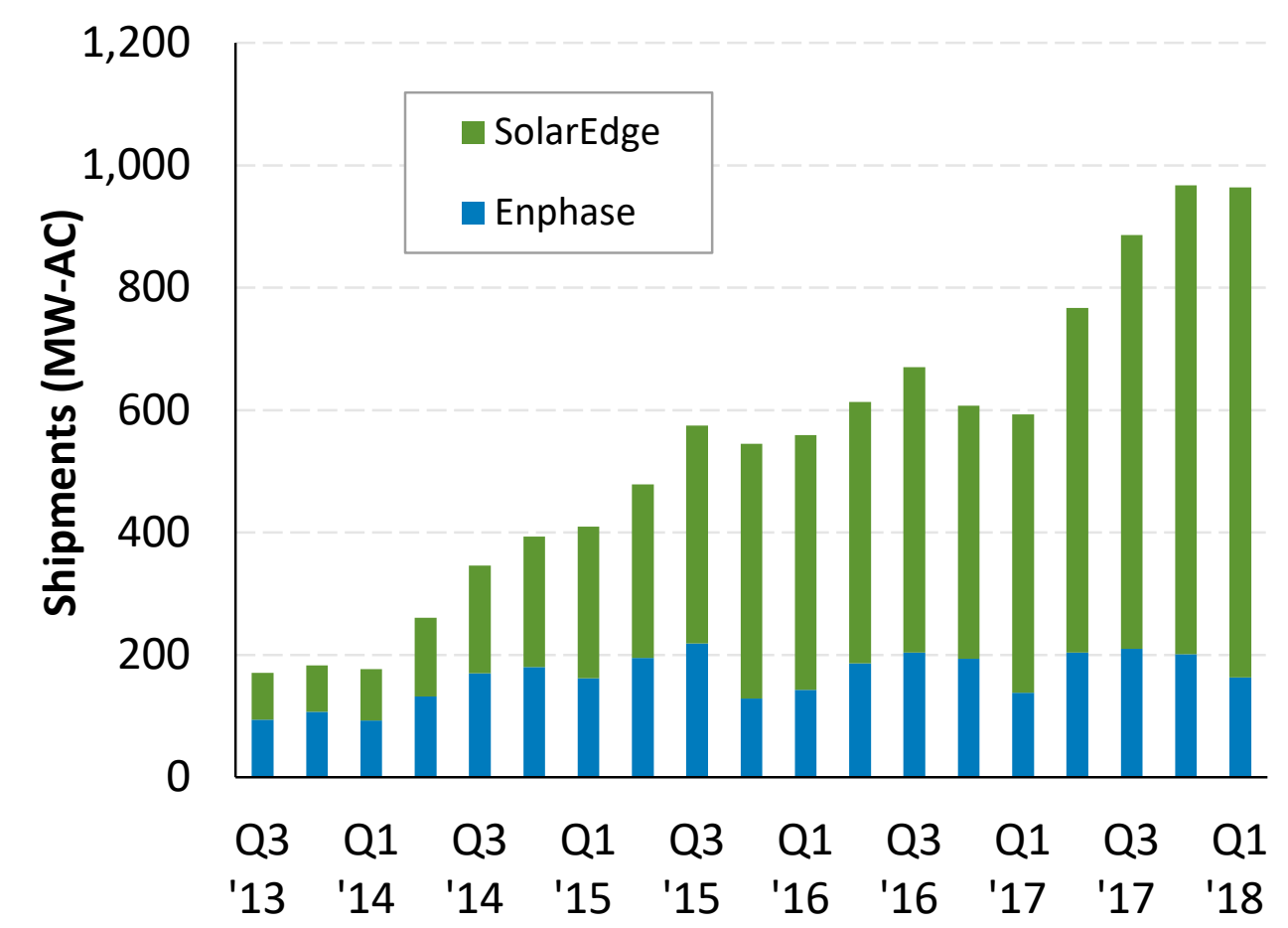

- In Q1 2018, Enphase and SolarEdge shipments grew $19 \%$ and $76 \%$ y/y respectively, with SolarEdge recording its highest quarter ever.

- In June 2018 it was announced that Enphase would acquire SunPower's microinverter business and become SunPower's exclusive supplier of microinverters.

- Microinverters represented $80 \%$ of SunPower's residential sales in Q1 2018-approximately $64 \mathrm{MW}$-DC. 


\section{Federal and State Updates}

\section{Global PV Deployment}

\section{U.S. PV Deployment}

\section{PV System Pricing}

\section{Global Manufacturing}

6 Component Pricing

7 Market Activity
- In the first half of 2018, SREC market pricing moved up and down in each market due to supply and demand dynamics, but there were no significant changes.

- While solar stocks outperformed the broader market in 2017, they tumbled significantly in May through July of 2018 due to lower expectations of global demand.

- 2017 was a record-breaking year with $\$ 1.3$ billion of solar asset-backed securities (ABS); this trend continues in $\mathbf{2 0 1 8}$ with over \$1 billion in the first six months. 


\section{Market Activity: SREC Pricing}

- Strong growth in the New Jersey non-residential market in 2017 led to expectations of an SREC price crash in 2018. However, in May, the state assembly passed legislation increasing the solar RPS carve-out from $4.1 \%$ in 2028 to $5.1 \%$ in 2021 , pulling a substantial amount of demand forward.

- The bill also reduced future project's SREC generating life from 15 years to 10 years.

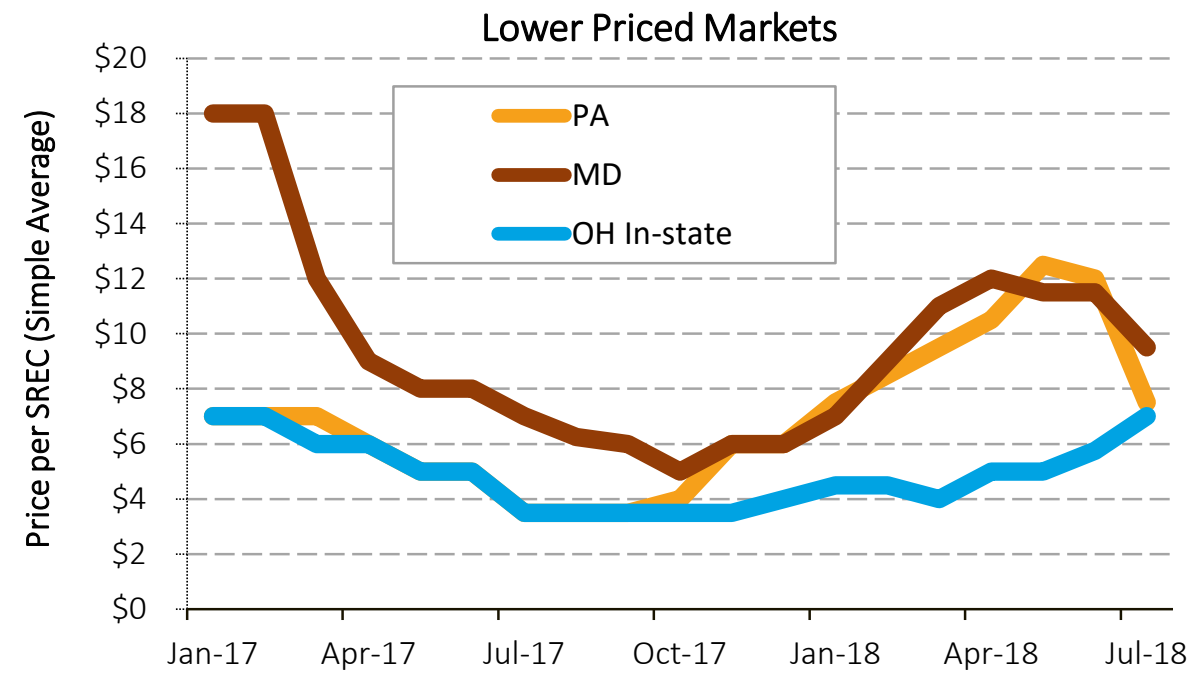

Sources: SRECTrade, www.srectrade.com (accessed 08/02/18).
- In the first half of 2018, SREC market pricing moved up and down in each market due to supply and demand dynamics, but there were no significant changes.

- DC pricing dropped due to potential buyers opting to pay the ACP rather than purchase SRECS.

- Pennsylvania SREC prices increased with the passage of a law in late 2017 that prohibited future out-ofstate facilities from selling PA SRECs; however, in April PA SREC pricing declined again due to market oversupply.

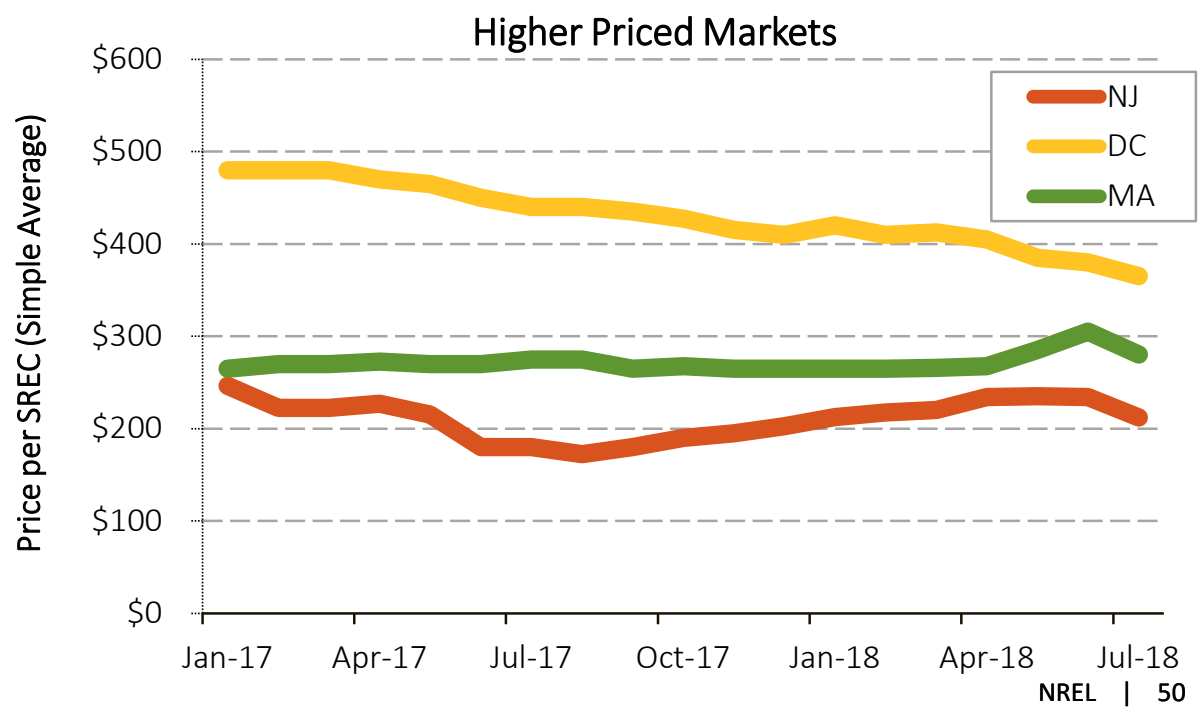




\section{Market Activity: Stock Market}

- While solar stocks outperformed the broader market in 2017, they tumbled significantly from May through July 2018.

- The TAN dropped $16 \%$ from May 21 to August 1 while the S\&P 500 increased $3 \%$ over that time.

\section{Returns Since January 2017}

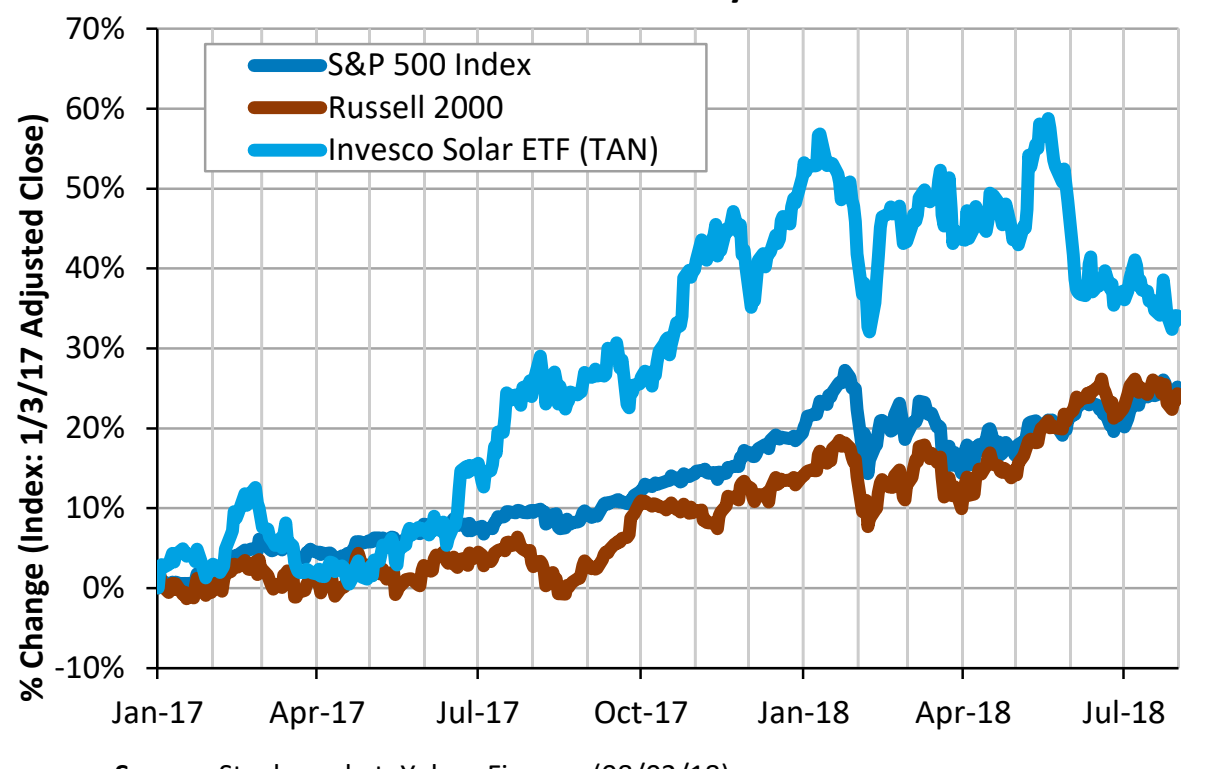

Source: Stock market: Yahoo Finance $(08 / 02 / 18)$.
- A large reason for the drop in stock prices in late May and early June is the announcement of a decrease in Chinese subsidies in 2018, which caused a significant oversupply of modules in the marketplace.

- While this is a negative for PV manufacturers, as demonstrated by the drop in price of First Solar's stock, installation companies, such as Sunrun and Vivint Solar, have benefited from this decision.

\section{Return Since Trade Case Filing}

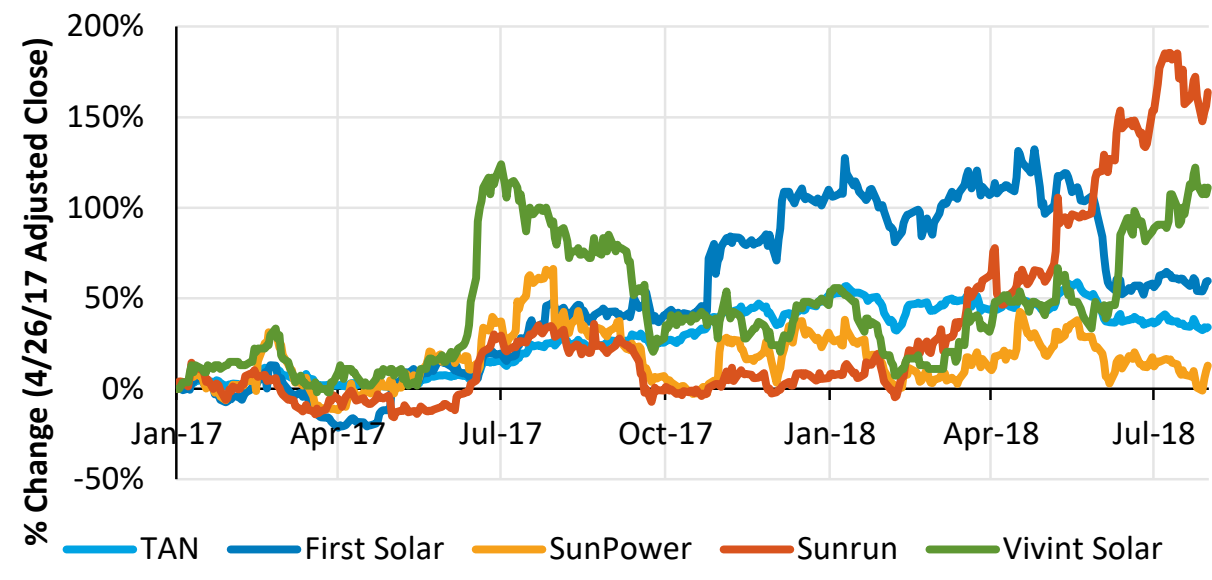




\section{Market Activity: Solar Securitizations}

\begin{tabular}{|c|c|c|c|c|}
\hline & Solar Mosaic (2018-1) & Dividend Solar (2018-1) & Vivint Solar (2018-1) & Solar Mosaic (2018-2-GS) \\
\hline Date & April 2018 & April 2018 & June 2018 & June 2018 \\
\hline Amount & $\begin{array}{l}\$ 195.8 \text { million Class A } \\
\$ 23.2 \text { million Class B } \\
\$ 16.3 \text { million Class C }\end{array}$ & $\begin{array}{l}\$ 25.3 \text { million Class } A \\
\$ 66.4 \text { million Class B } \\
\$ 6.6 \text { million Class C } \\
\$ 6.3 \text { million Class D }\end{array}$ & $\begin{array}{l}\$ 400 \text { million Class } A \\
\$ 66 \text { million Class B }\end{array}$ & $\begin{array}{l}\$ 273.8 \text { million Class A } \\
\$ 17.0 \text { million Class B } \\
\$ 15 . \text { million Class C } \\
\$ 11.6 \text { million Class D }\end{array}$ \\
\hline Rate & $\begin{array}{l}\text { Class A - C (4.0\%; } 2.0 \% \text {; } \\
\text { principal only) }\end{array}$ & $\begin{array}{l}\text { Class A - D (2.61\%; } 4.29 \% \\
5.15 \% ; 6.39 \%)\end{array}$ & $\begin{array}{l}4.73 \% \text { Class A } \\
7.37 \% \text { Class B }\end{array}$ & $\begin{array}{l}\text { Class A - D (4.2\%; } 4.74 \% ; \\
5.97 \% ; 7.44 \%)\end{array}$ \\
\hline Rating & Class $A-D(A, B B B, B B)$ & Class $A-D(A A, A, B B B, B B)$ & $\begin{array}{l}\text { A- Class A } \\
\text { BB- Class B }\end{array}$ & Class A - D (A-, BBB-, BB-, B) \\
\hline
\end{tabular}

- 2017 was a record-breaking year with $\$ 1.3$ billion of solar $A B S$, up from $\$ 321$ million in 2016.

- This trend continues in 2018 with over $\$ 1$ billion in the first six months (not including a \$345 million private placement by Vivint Solar). 


\section{Market Activity: Proxy Revenue Swaps}

- Risk-transfer products, such as volume puts or swaps, are now fairly common in the renewable energy space.

- Many corporate PPAs use this model through a fixed-for-floating swap, which hedges the corporation and the PV asset against wholesale price volatility.

- A new product, the proxy revenue swap, hedges against "shape risk" (i.e., the production profile of a plant) in addition to price and volume risk.

- Because solar energy production is highly correlated between assets, the large amount of energy they produce, or stop producing, contemporaneously can significantly affect the energy market clearing price in areas with high penetration. Therefore, when power is produced can be as important, or more so, than the average price of energy.

- First introduced in 2016 in the wind industry, the proxy revenue swap product is now being offered to solar projects.
In the example below, two systems that produce the same amount of energy in a market can receive different revenues in the same market

\begin{tabular}{|lrrrr|}
\hline Flat Production Profile & & & & \\
\hline Hour & 11 & 12 & 13 & Total \\
\hline Production & 100 & 100 & 100 & $\mathbf{3 0 0}$ \\
\hline Price $(\$ / M W h)$ & $\$ 35$ & $\$ 20$ & $\$ 35$ & \\
\hline Revenue & $\$ 3,500$ & $\$ 2,000$ & $\$ 3,500$ & $\mathbf{\$ 9 , 0 0 0}$ \\
\hline
\end{tabular}

\begin{tabular}{|lrrrr|}
\hline Shaped Production Profile & & & \\
\hline Hour & 11 & 12 & 13 & Total \\
\hline Production & 80 & 140 & 80 & $\mathbf{3 0 0}$ \\
\hline Price $(\$ / M W h)$ & $\$ 35$ & $\$ 20$ & $\$ 35$ & \\
\hline Revenue & $\$ 2,800$ & $\$ 2,800$ & $\$ 2,800$ & $\$ \mathbf{8 , 4 0 0}$ \\
\hline
\end{tabular}




\section{Market Activity: Proxy Revenue Swaps, cont.}

- Under a proxy revenue swap contract:

- The hedge provider owes the project a fixed lump sum per quarter, regardless of the volume of electricity produced, the wholesale clearing price, or the solar irradiance.

- The project owes the hedge provider a floating amount each quarter equal to the sum of all "proxy revenue" calculated per settlement period in the relevant electricity market in a quarter.

- Proxy revenue for a given settlement period is calculated as the hub price multiplied by the project's "proxy generation" for the settlement period.

- Proxy generation is determined using a pre-agreed formula that converts irradiance into electricity output.

- The difference between the lump sum and the sum of proxy revenue determines which party pays the other in a given quarter. For example, if the lump sum amount is worth more than the sum of proxy revenue, the project receives the difference (making up for the lower revenue they received from their actual electricity sales).

- The project is hedged against volume, price, and irradiance by receiving a fixed payment each quarter unrelated to project output.

- Similar to the fixed-for-floating contract, there is basis risk between the hub price, where the contract price is determined, and the nodal price, where project revenue is determined. 


\section{Market Activity: Proxy Revenue Swaps- An Example}

1) If proxy revenue $>$ fixed payment

- Higher insolation

- Higher hub price

- Solar project generates more revenue in wholesale market.

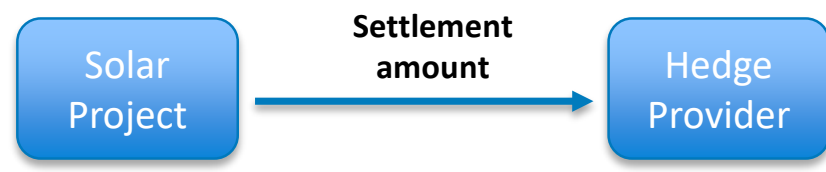

More electricity or at higher value

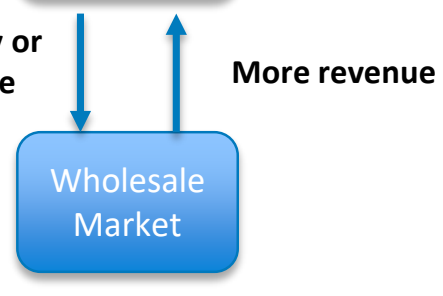

2) If proxy revenue < fixed payment

- Lower insolation

- Lower hub price

- Solar project generates less revenue in wholesale market.

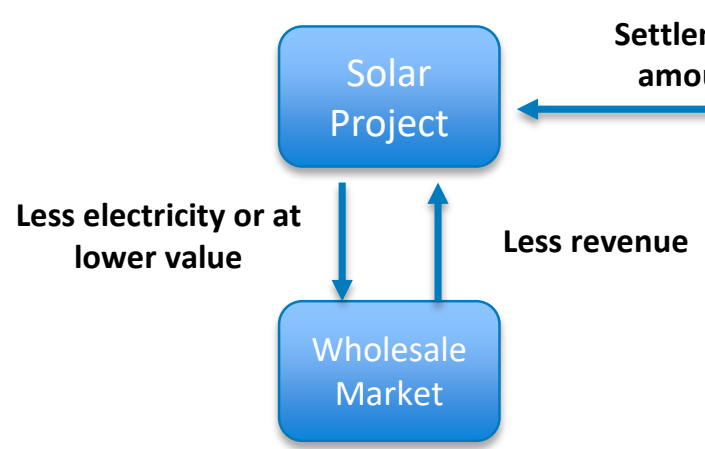
Formulas
Proxy Revenue $_{T}=$ Hub Price $_{T} \times$ Proxy Generation $_{T}$
Proxy generation determined by solar irradiance at project site
Settlement Amount $=\mid$ Fixed Payment $-\sum$ Proxy Revenue $\mid$ 


\section{Key Performance Indicators of CRFI Loan \\ Portfolio of 6,770 Solar Loans}

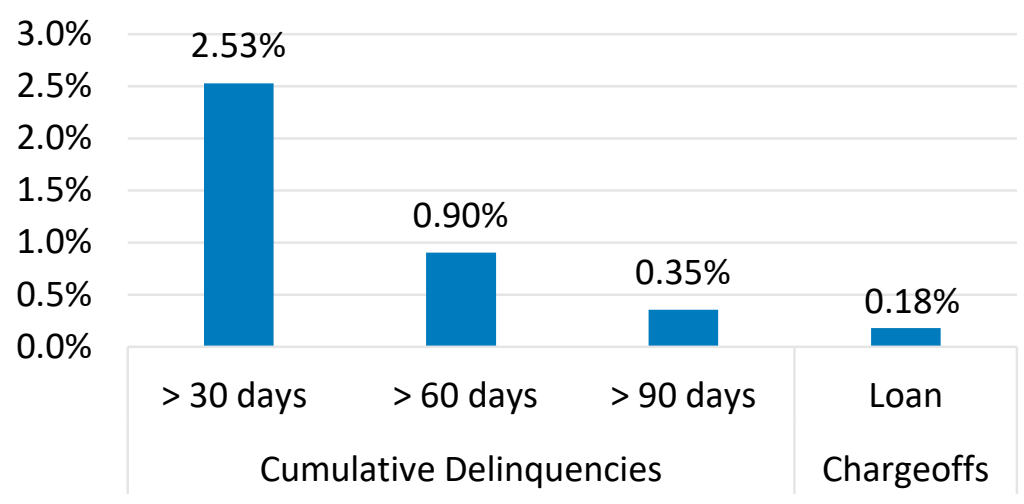

- A sampling of CRFI perspectives collected from industry interviews indicates positive experiences with the development and evolution of PV loans. Quantitative data on 6,770 loans representing over $\$ 186$ million in PV lending also suggest PV loans are performing very well to date, although these results must be put in the context of the high credit quality of borrowers, the early state of the loans, and the recent robust economy.

- Although most CRFI investment to date has targeted standalone distributed PV, other applications will likely emerge, such as community PV and PV coupled with battery storage.

- Access to additional credit and market information is critical for accelerating the role of CRFIs and other financial institutions in supporting U.S. PV growth.

\section{Borrower's Credit Score Profile \\ (6,770 Solar Loan Portfolio)}

\section{a $\leq 680 \square 681-719 \square \geq 720$}




\title{
Thank You
}

\author{
www.nrel.gov
}

NREL/PR-6A20-72036

Special thanks to Dan Bilello, Anna Ebers, Jeff Logan, Mike Meshek, Tariq Shanks, and Paul Schwabe. 


\section{List of Acronyms and Abbreviations}

\begin{tabular}{|c|c|}
\hline ABS & asset-backed security \\
\hline $\mathrm{AC}$ & alternating current \\
\hline ACP & alternative compliance payment \\
\hline$A D+C V D$ & anti-dumping and countervailing duties \\
\hline ASP & average selling price \\
\hline BIPV & building integrated photovoltaic \\
\hline BNEF & Bloomberg New Energy Finance \\
\hline $\mathrm{C}-\mathrm{Si}$ & crystalline silicon \\
\hline $\mathrm{CHP}$ & combined heat and power \\
\hline CRFI & community and regional financial institutions \\
\hline CSP & concentrating solar power \\
\hline DC & direct current \\
\hline DG & distributed generation \\
\hline EIA & Energy Information Administration \\
\hline ETF & exchange traded fund \\
\hline FIT & feed-in-tariff \\
\hline G\&A & general and administrative expenses \\
\hline GW & gigawatt \\
\hline GWh & gigawatt-hour \\
\hline ILR & inverter loading ratio \\
\hline IPR & intellectual property rights \\
\hline IRS & Internal Revenue Service \\
\hline ITC & investment tax credit \\
\hline $\mathrm{kg}$ & kilogram \\
\hline kW & kilowatt \\
\hline kWh & kilowatt-hour \\
\hline
\end{tabular}

MLPE

- MW

- MWh

NEM

- NYSE

- PPA

- PSC

- PTC

- PV

- Q

- RPS

- S\&P

- SEIA

- SEPA

- SG\&A

- SREC

- tan

- tou

- tPO

- ustr

- W

- WTO

- $y / y$ module-level power electronics

megawatt

megawatt-hour

net energy metering

New York Stock Exchange

power purchase agreement

public service commission

production tax credit

photovoltaic

quarter

renewable portfolio standards

Standard and Poor's

Solar Energy Industries Association

Smart Electric Power Alliance

selling, general, and administrative expenses

solar renewable energy certificate

Invesco Solar ETF

time of use

third-party owner

United States Trade Representative

watt

World Trade Organization

year over year

kilowatt 